\title{
A Candida albicans early stage biofilm detachment event in rich medium
}

\author{
Adnane Sellam ${ }^{\dagger 1}$, Thamir Al-Niemi ${ }^{\dagger 2}$, Kathleen McInnerney ${ }^{3}$, \\ Susan Brumfield ${ }^{2}$, Andre Nantel ${ }^{1}$ and Peter A Suci*4
}

\begin{abstract}
Address: ${ }^{1}$ Biotechnology Research Institute, National Research Council of Canada, Montreal, Quebec, Canada, ${ }^{2}$ Department of Plant Sciences and Plant Pathology, Montana State University, Bozeman, MT 59717, USA, ${ }^{3}$ Genomics Core Facility, Department of Microbiology, Montana State University, Bozeman, MT 59717, USA and ${ }^{4}$ Department of Microbiology and Center for Biofilm Engineering, Montana State University, Bozeman, MT 59717, USA

Email: Adnane Sellam - adnane.sellam@cnrc-nrc.gc.ca; Thamir Al-Niemi - thamir@montana.edu; Kathleen McInnerney - kmcinnerney@montana.edu; Susan Brumfield - uplsb@montana.edu; Andre Nantel - andre.nantel@cnrc-nrc.gc.ca; Peter A Suci* - peter_s@erc.montana.edu

* Corresponding author †Equal contributors
\end{abstract}

Published: 2 February 2009

BMC Microbiology 2009, 9:25 doi:10.1 I86/|47|-2180-9-25
Received: 8 August 2008

Accepted: 2 February 2009

This article is available from: http://www.biomedcentral.com/I47I-2/80/9/25

(C) 2009 Sellam et al; licensee BioMed Central Ltd.

This is an Open Access article distributed under the terms of the Creative Commons Attribution License (http://creativecommons.org/licenses/by/2.0), which permits unrestricted use, distribution, and reproduction in any medium, provided the original work is properly cited.

\begin{abstract}
Background: Dispersal from Candida albicans biofilms that colonize catheters is implicated as a primary factor in the link between contaminated catheters and life threatening blood stream infections (BSI). Appropriate in vitro C. albicans biofilm models are needed to probe factors that induce detachment events.

Results: Using a flow through system to culture C. albicans biofilms we characterized a detachment process which culminates in dissociation of an entire early stage biofilm from a silicone elastomer surface. We analyzed the transcriptome response at time points that bracketed an abrupt transition in which a strong adhesive association with the surface is weakened in the initial stages of the process, and also compared batch and biofilm cultures at relevant time points. $\mathrm{K}$ means analysis of the time course array data revealed categories of genes with similar patterns of expression that were associated with adhesion, biofilm formation and glycoprotein biosynthesis. Compared to batch cultures the biofilm showed a pattern of expression of metabolic genes that was similar to the $C$. albicans response to hypoxia. However, the loss of strong adhesion was not obviously influenced by either the availability of oxygen in the medium or at the silicone elastomer surface. The detachment phenotype of mutant strains in which selected genes were either deleted or overexpressed was characterized. The microarray data indicated that changes associated with the detachment process were complex and, consistent with this assessment, we were unable to demonstrate that transcriptional regulation of any single gene was essential for loss of the strong adhesive association.
\end{abstract}

Conclusion: The massive dispersal of the early stage biofilm from a biomaterial surface that we observed is not orchestrated at the level of transcriptional regulation in an obvious manner, or is only regulated at this level by a small subpopulation of cells that mediate adhesion to the surface. 


\section{Background}

Members of the Candida genus are the principal etiological agents of nosocomial fungal infections, with C. albicans being the most common species [1-3]. The overall mortality rate for patients with candidemia is greater than $40 \%$ [4-6]. Catheters are considered to be a likely point of entry of $C$. albicans into the vascular system [7]. In support of this evaluation, a particularly high risk of invasive candidiasis is associated with the use of urinary and vascular catheters, and ventricular assist devices [8]. The chances of acquiring a BSI resulting from colonization of an intravascular catheter by Candida species has been ranked high among pathogens involved in biomaterial centered infections, second only to Staphylococcus aureus [9]. C. albicans colonizes various biomaterials and readily forms dense, complex biofilms under a variety of in vitro conditions [10]. C. albicans biofilms exhibiting similar architectural and morphological features form in vivo [11-13]. The implication is that dissemination from C. albicans biofilms colonizing biomaterials is frequently a major factor predisposing susceptible patients to life threatening BSI.

Despite the evidence that dispersal of cells from C. albicans biofilms may be a critical step in biomaterial related cases of candidemia, few studies have characterized C. albicans biofilm detachment behavior. Daughter cells that are released from C. albicans biofilms cultured on cellulose acetate filters or cellulose fibers perfused with a continuous flow of medium have been collected either as a means to assess biofilm growth rate [14], or to determine if dispersed cells retain the intrinsic (transient) phenotypic resistance to antimicrobials that is a hallmark of biofilms [15]. In the former study there is an implicit (untested) hypothesis that the detachment rate is constrained by the medium substrate loading rate, and not simply a direct (passive) response to the applied (mechanical) shear force. Expression of a GPI (glycosylphosphaditylinositol) anchored cell wall protein (Ywp1p) has been shown to decrease adhesion between biofilms composed of yeast forms and a polystyrene surface [16]. The implication is that Ywp1p may be the effective structural component in an active control network that induces biofilm detachment. A recent review has discussed cell dispersal from $C$. albicans biofilms with respect to its possible induction by farnesol, a quorum sensing agent that promotes formation of the yeast form [17]. C. albicans biofilms formed from mutants in which genes coding for key adhesins under the positive control of the Bcr1p transcription factor have been disrupted produce thin fragile biofilms $[11,18]$. Detachment of cells from biofilms formed from these mutant strains is significantly enhanced [19].

Evidence is accumulating that bacterial biofilms actively regulate dispersion processes using a variety of mechanisms [20-28]. The aim of the present study was to deter- mine if we could find evidence indicating that $C$. albicans biofilm detachment from a biomaterial surface was actively regulated at the level of transcription. A clearly observable, reproducible transition between establishment of strong adhesion and loss of adhesion in a relatively copious early stage biofilm provided us with a simple tractable in vitro system for probing changes in the transcriptome associated with loss of adhesive bonds to a biomaterial. Since the phenomenon involved the entire biofilm population we could apply a relatively simple scheme for array analysis which consisted of a closed loop time course comparison. A comparison of biofilm and batch cultures provided us with an additional way to screen for genes that were specifically involved in the detachment process.

\section{Results \\ The detachment process involves an early abrupt loss of strong adhesion}

Biofilms were cultured in a tubular reactor similar to that used in a previous study [29] (Figure 1). Figure 2a shows stages of biofilm detachment that are evident from visual inspection of the silicone elastomer tubing in which the biofilms were cultured. Regions where the biofilm has been displaced from the tubing become visible by $2 \mathrm{~h}$ and continue to enlarge during the course of development. These regions of detachment are evident along the entire length of the tubing. Biofilms cultured for $6 \mathrm{~h}$ appear to have only minimal points of contact with the silicone elastomer. Typically, this tenuous association is completely lost between 8 and $9 \mathrm{~h}$, at which point the entire biofilm is displaced downstream by the flow.

As in other C. albicans biofilm studies [11,30-33], our inoculum was produced at $30^{\circ} \mathrm{C}$ in order to obtain a well defined dispersed population consisting entirely of yeast singlets and doublets, with no cell aggregates. This relatively large inoculum settles to the lower surface of the tubing during the $1 \mathrm{~h}$ incubation period. These cells, which still have the yeast morphology after the $1 \mathrm{~h}$ incubation period, are completely removed if the tubing is drained, leaving the lower tubing surface completely free of cells (data not shown). Contrary to our initial expectation, when medium flow is initiated, most cells remain associated with the surface. We found less than $10^{5}$ cells/ $\mathrm{ml}$ in aliquots collected immediately after initiation of flow until just before loss of the entire biofilm (five experiments). Cells that remain associated with the surface germinate and the biomass increases primarily by hyphal extension rather than increase in cell number (Figure 2c). (A batch culture in which the conditions of the inoculation are the same behaves similarly in this respect). Biofilms grown for $1 \mathrm{~h}$ have developed a multilayer, multicellular structure that remains associated with the tubing after it is subjected to the large shear forces exerted 
air vent

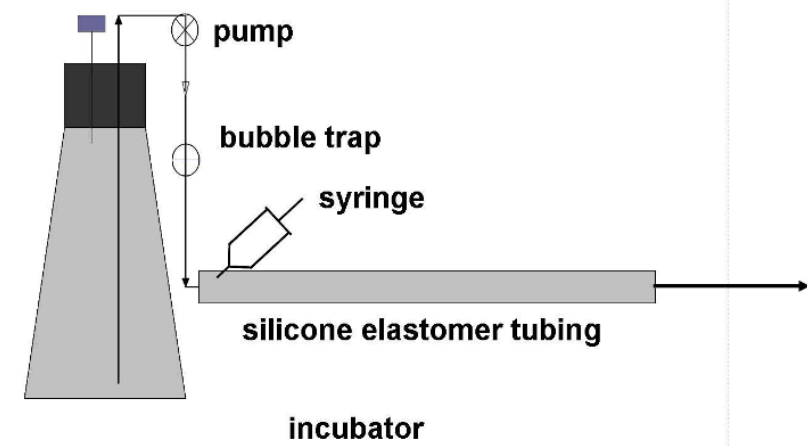

Figure I

Biofilm tubular reactor. The reactor was inoculated by drawing a cell suspension into the tube from the effluent end (arrow) using a sterile syringe inserted through the tubing wall just down stream from the bubble trap. The bubble trap also serves as a sterility barrier. The entire system was enclosed in an incubator for temperature control (broken line).

at the interface by draining the tubing (Figs $2 \mathrm{~d}$ and $2 \mathrm{e}$ ), indicating that as cells germinate they rapidly develop relatively strong cell to cell (cohesive) and cell to surface (adhesive) bonds.

The relatively strong adhesive association with the surface that is established by $1 \mathrm{~h}$ is weakened considerably before visible regions of the biofilm lift off the tubing and this is accompanied by a change in biofilm morphology. The early time course of this loss of adhesion was followed using cryosectioning, scanning electron microscopy (SEM) and time lapse photography (Figure 3). Cryosections of the biofilm indicated that there was a fairly abrupt transition in the structural organization of regions of the biofilm (particularly regions near the biofilm lateral edges) consisting of the appearance of hyphae extending into the surrounding medium between 60 and $90 \mathrm{~min}$ (Figure 3a). Characterization of the surface using SEM showed that the abrupt structural transition was coincident with the loss of adhesion to the surface (Figure $3 \mathrm{~b}$ ). At 30 and $60 \mathrm{~min}$ a multilayer biofilm remained after draining the tubing while at later time points (90 and 120 min) most of the cells were displaced by draining. No cells could be found on the lower (previously colonized) surface after draining tubing containing a $3 \mathrm{~h}$ biofilm (data not shown). Time lapse photography of the top of the biofilm during the transition indicated that macroscopic detachment was first visible at the edges of the biofilm as wavy flaps (Figure 3c). At later times wrinkles appeared in the biofilm that, when viewed from the side, were evidently locations at which portions of the biofilm had been entirely displaced from the surface.
The structural reorganization observed at the 90 and 120 min time points becomes more pronounced as the biofilm develops. Sections of $3 \mathrm{~h}$ biofilms were obtained transverse to the direction of flow (in the plane of the tubing cross-section) (Figure 4). The structure of the sections prepared using the Spurr's embedding method (Figure 4a) appeared quite similar to those prepared using cryosectioning, a histological technique that was designed to preserve the hydrated structure (Figure $4 \mathrm{~b}$ ). Both sectioning techniques indicated a structure in which hyphae extended from both sides of the detached biofilm into the surrounding medium. Despite their relative immaturity, the $3 \mathrm{~h}$ biofilms showed evidence of production of extracellular polymeric substance (EPS) as indicated by staining with a monoclonal antibody against $(1,3) \beta$ glucan (Figure $4 \mathrm{c}$ and $4 \mathrm{~d}$ ). A previous study indicated that $(1,3)$ $\beta$ glucan is a primary component of $C$. albicans EPS [34]

Table 1 summarizes the hydrodynamic (shear) forces associated with displacement of the biofilm from the tubing at various stages of growth. (The approximate dimensions of the $3 \mathrm{~h}$ biofilm with respect to the tubing were indicated in Figure 2b). The yeast inoculum was not rinsed from the surface by the relatively low shear force

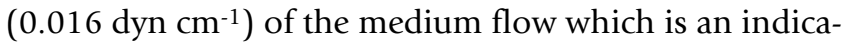
tion that this hydrodynamic force is quite gentle. However, it was completely displaced from the surface by draining the tubing (data not shown). In contrast biofilms cultured for between $30 \mathrm{~min}$ and $1 \mathrm{~h}$ have established a sufficiently firm adhesion so that the biofilm can withstand application of a substantial shear force (17.3 dynes/ $\mathrm{cm}^{2}$ ).

\section{Initial biofilm adhesion is dependent on expression of $B C R I$ and ALS3 but not on HWPI}

A simple hypothesis is that the loss of adhesion described above involves a temporal shift in expression of two adhesins (ALS3 and HWP1), regulated by the BCR1 transcription factor, that were shown play a prominent role in C. albicans biofilm development $[11,19,35]$. In order to pursue this idea we first determined if these genes were involved in establishment of the initial strong adhesive bond to the surface. Figure 5 shows that at $40 \mathrm{~min}$ the reference (wild type) strain has established adhesion to the tubing surface while the $b c r 1 / b c r 1$ and als3/als3 mutant biofilms are almost completely displaced from the surface by draining the tubing. BCR1 is a positive regulator of morphogenesis. However, the lack of establishment of adhesion of $b c r 1 / b c r 1$ and als3/als3 strains was not entirely coupled to filamentation in a simple manner since a substantial proportion of the $b c r 1 / b c r 1$ and als3/als 3 mutant cells germinated (20 and $70 \%$ ) during the $40 \mathrm{~min}$ time interval. (The mean germ tube length of these cells was 14 $+/-12$ and $10+/-7 \mu \mathrm{m}$, respectively). The results for the hwp1/hwp1 mutant indicated that expression of this gene 

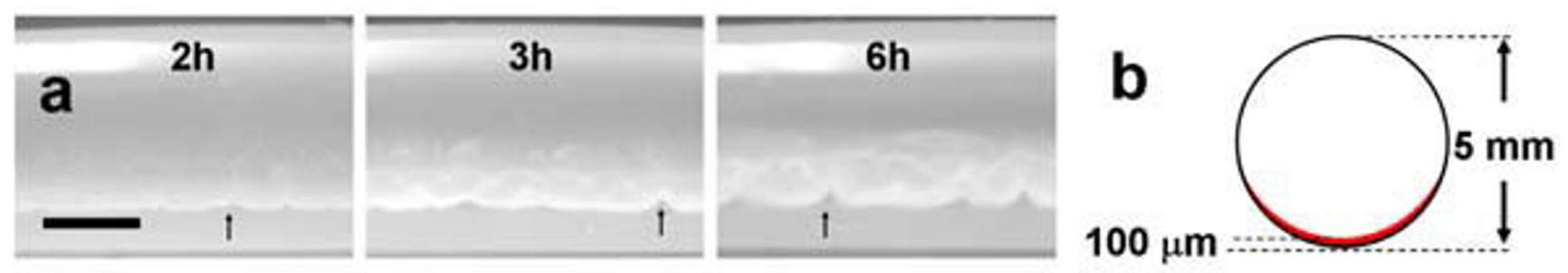

C
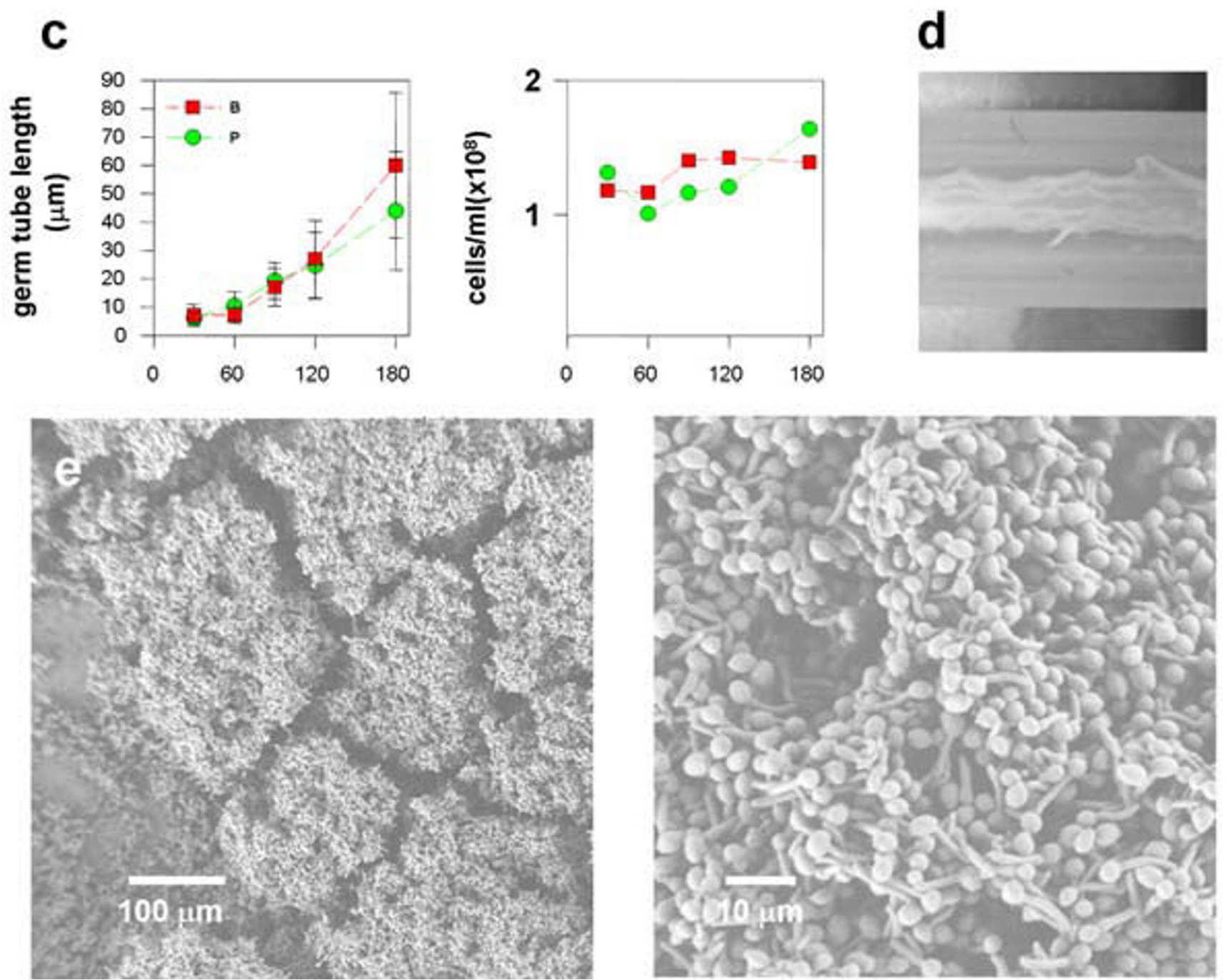

\section{Figure 2}

Biofilm detachment process. a) Images of the biofilm in the tubing (side view) at various time points; regions where the biofilm has been displaced from the lower surface are indicated by arrows; a similar pattern of detachment was observed in more than 100 experiments; the scale bar is $2 \mathrm{~mm}$; b) Approximate dimensions of the $3 \mathrm{~h}$ biofilm with respect to the tubing cross section; c) Changes in germ tube and cell density versus time; Legend: B, biofilm, P, planktonic (batch) culture; (By I h $82 \%$ and $76 \%$ of the cells geminated in biofilm and planktonic cultures, respectively);d) The multilayer biofilm that remains on the surface after draining at times up until I $\mathrm{h}$ extends along the trough of the tubing and is visible; (Representative digital camera image of the underside of the tubing); e) SEM images of the I $\mathrm{h}$ biofilm that remains on the lower surface of the tubing after draining. 
a

$30 \mathrm{~min}$

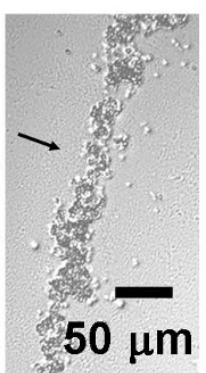

$60 \mathrm{~min}$

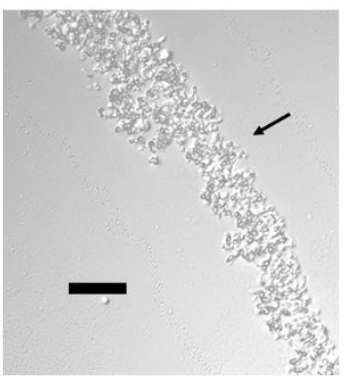

$90 \mathrm{~min}$

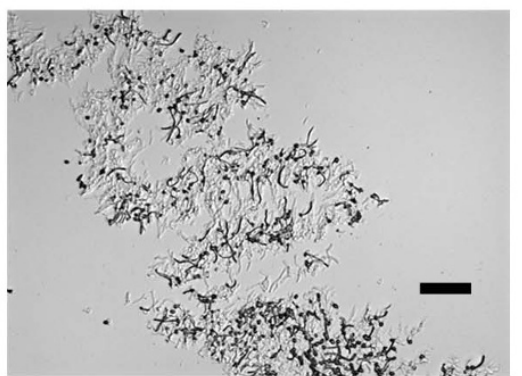

$120 \mathrm{~min}$

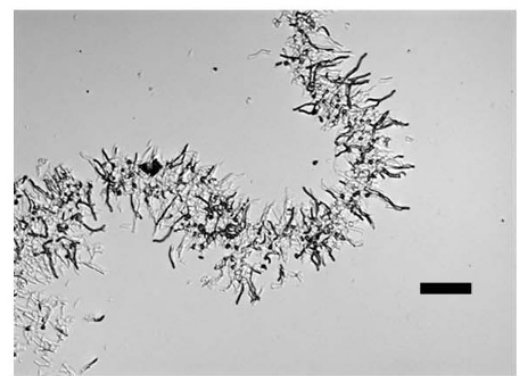

b

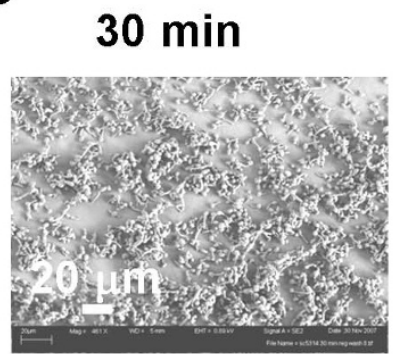

$60 \mathrm{~min}$

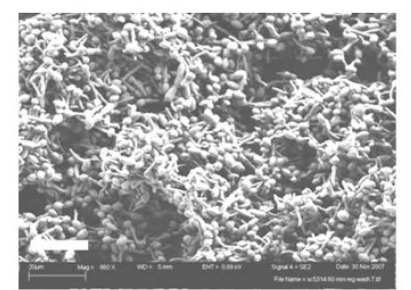

$90 \mathrm{~min}$

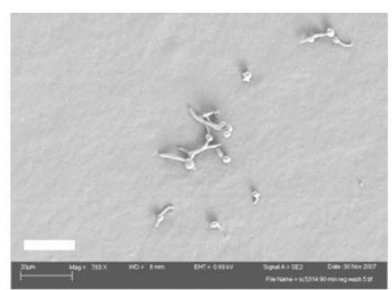

$120 \mathrm{~min}$

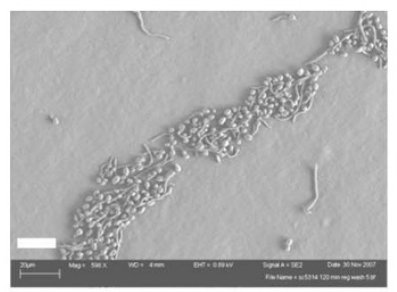

C
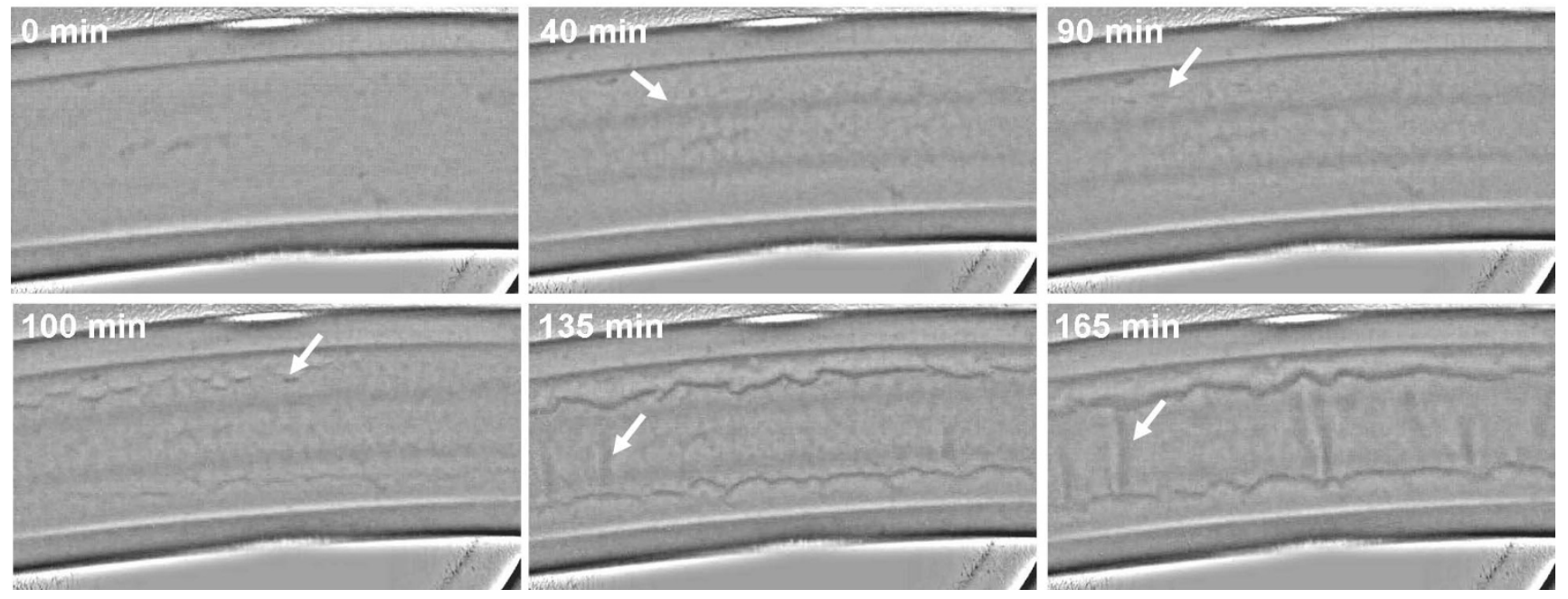

\section{Figure 3}

Time course of loss of adhesion and accompanying microscopic and macroscopic structural changes. a) Cryosections of biofilms at different time points. Sections acquired at 30 and $60 \mathrm{~min}$ appear to conform to the curved surface of the tubing. Arrows indicate substratum side. The structure in which hyphae at the edges extend into the surrounding medium becomes apparent between 60 and $90 \mathrm{~min}$. (Scale bars are all $50 \mu \mathrm{m}$ ). b) SEM images of the colonized (lower) surface of the tubing after the tubing was drained. Between 60 and 90 min there is a sharp transition in which most of the cells have lost their surface adhesion. (Scale bars are all $20 \mu \mathrm{m}$ ). c) Time course of gross structural changes during loss of adhesion. The biofilm is visible at $40 \mathrm{~min}$. At $90 \mathrm{~min}$ the flanking sections detach as flaps (arrow); these flaps are more visible at later time points. At 135 min wrinkles begin to form (arrow) and become more prominent at later time points ( $185 \mathrm{~min}$ ). 

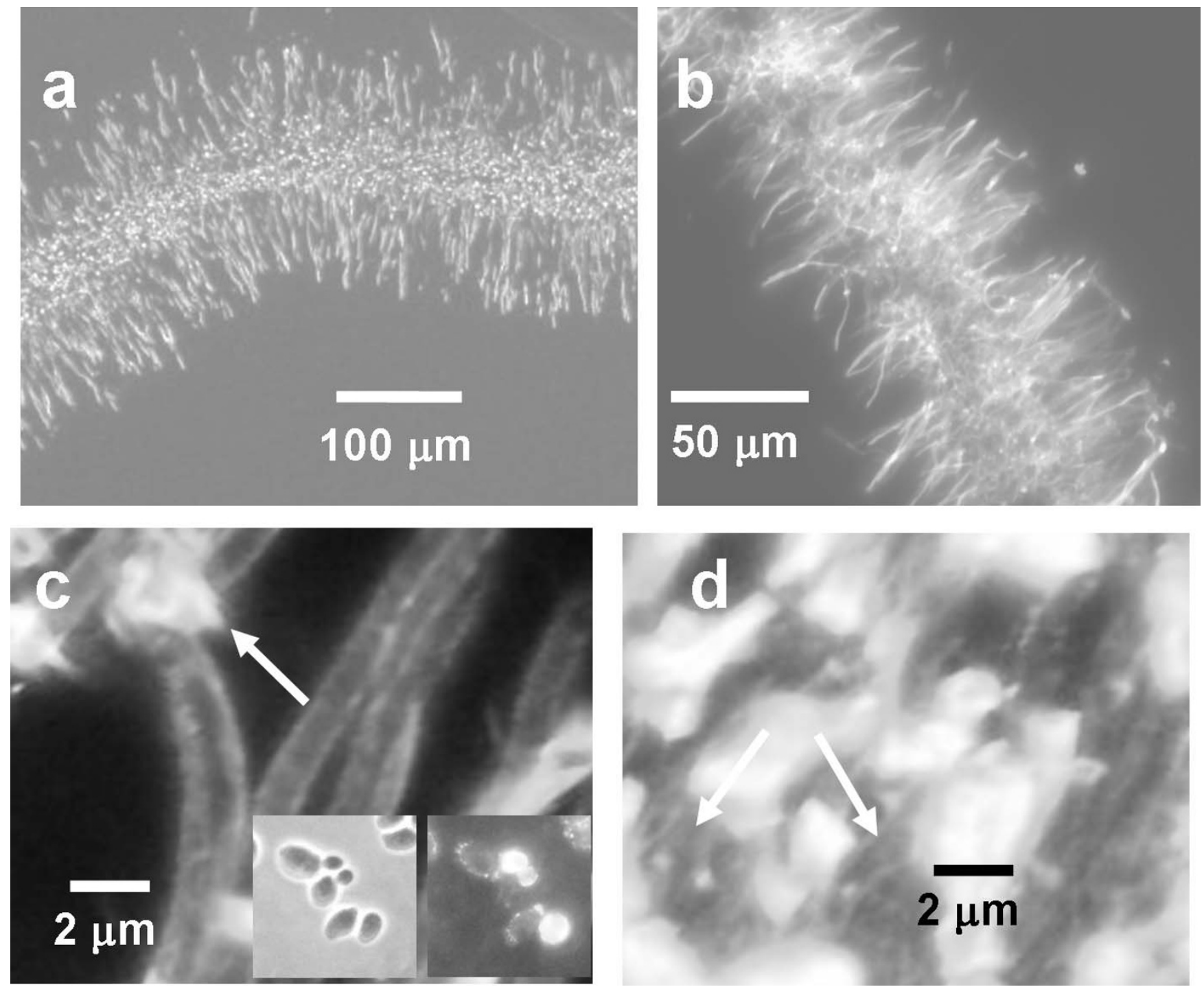

\section{Figure 4}

Detached biofilm structure ( $3 \mathbf{~ h}$ biofilms). All images were acquired using epi-fluorescence microscopy. a) Spurr's embedded section; the fluorescence originates from the preparation technique; b) Cryosection stained with calcofluor white; c, d) Cryosections stained for $(I, 3) \beta$ glucan; c) Region at the edge of the biofilm; arrow indicates extracellular material that is stained; inset is the planktonic positive control (left: transmitted image right: epi-fluorescence image); d) region in the interior of the biofilm; arrows indicate stained material that appears as strands.

was not essential for establishment of firm adhesion, i.e. under our conditions and at this early stage in biofilm development. At 40 min the biofilm was multilayered and clearly attached. These results led us to characterize the detachment phenotype of a strain that overexpressed ALS3 which is described below.

\section{Comparison of the firmly and loosely attached biofilm suggests that glycosylation, vesicle trafficking and transport contribute to the adhesive phenotype}

As shown in Figure (2d and $2 \mathrm{e}$ ) a visible multilayered biofilm structure withstands the substantial shear force applied by draining the tubing for biofilms cultured for 1 $\mathrm{h}$. A portion of the $1 \mathrm{~h}$ biofilms is typically removed from the surface by this procedure. These two subpopulations are referred to as the $1 \mathrm{~h}$ firmly ( $1 \mathrm{~h} \mathrm{~F}$ ) and $1 \mathrm{~h}$ loosely ( $1 \mathrm{~h}$ $\mathrm{L})$ attached biofilm. We reasoned that comparing the transcriptional profiles of these two subpopulations might uncover genes that were subsequently differentially regulated to mediate detachment in our flow model. The comparison of $1 \mathrm{~h} \mathrm{~F}$ and $1 \mathrm{~h} \mathrm{~L}$ biofilms revealed 22 upregulated and 3 repressed transcripts (see Additional file 1). Upregulated genes fell into process ontological categories of vesicular trafficking, glycosylation and transport. RT- 
Table I: Hydrodynamics of biofilm displacement from the surface

\begin{tabular}{lcc}
\hline & \multicolumn{2}{c}{ Shear Force (dynes/cm 2$)^{\perp}$} \\
& $\underline{0.016}$ & $\underline{17.3}$ \\
\hline Yeast inoculum & & - \\
30 min-I h Biofilm & + & + \\
$2-6$ h Biofilm & + & - \\
$>8$ h Biofilm & + & - \\
\hline
\end{tabular}

'Computed as indicated in the Methods section

${ }^{2}$ At the end of the $\mathrm{I} \mathrm{h}$ inoculation period

+ biofilm remains attached

- biofilm is removed

qPCR confirmed the changes in transcript levels of some genes enriched in glycosylation and vesicle trafficking functions that exhibited relatively small fold changes (Table 2). The distinct pattern of expression of these genes within the context of the time course analysis is discussed in the next section.

reference
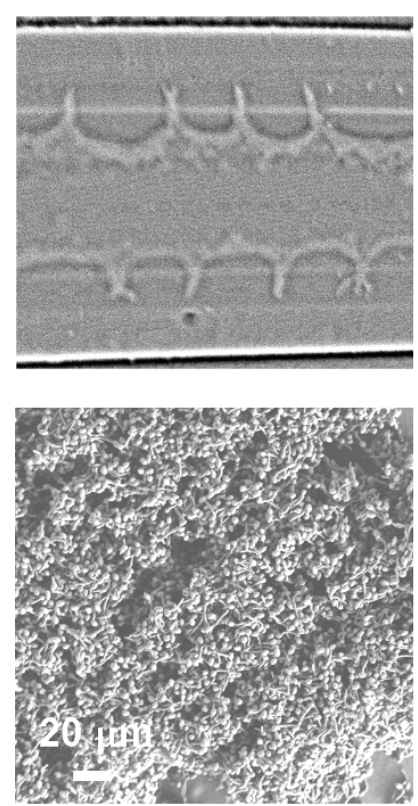

hpw1/hwp1
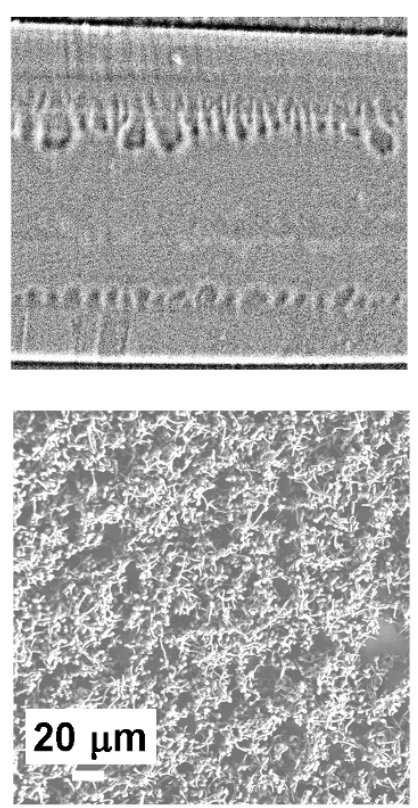

Time course analysis indicates detachment is associated with coordinated expression of mutually exclusive functional categories

In order to identify changes in the transcriptome that accompanied the abrupt detachment event we performed a closed loop time course analysis (Figure 6a). In such a comparison, each sample is compared to two or more other conditions thus allowing us to visually validate the changes in transcript abundance. We compared the transcriptome of $1 \mathrm{~h} \mathrm{~F}$ and $1 \mathrm{~h} \mathrm{~L}$ biofilms with biofilms that had spontaneously and progressively lost their adhesive bonds ( 3 and $6 \mathrm{~h}$ ). The time course array analysis produced 148 predicted ORFs that were differentially regulated ( $>=1.5$ fold change, P-value $<0.05$ ) for at least one pair wise comparison (Figure 6b). (The complete list of genes that are significantly modulated in each comparison is presented in Additional file 1). Of the 148 differentially regulated genes, 98 have a known inferred function. There were also 34 genes that were significantly up or down regulated in more than one pair wise condition (see Additional file 1). Comparison with two previous studies $[36,37]$ in which cells were transferred from $30^{\circ} \mathrm{C}$ to $37^{\circ} \mathrm{C}$

bcr1/bcr1
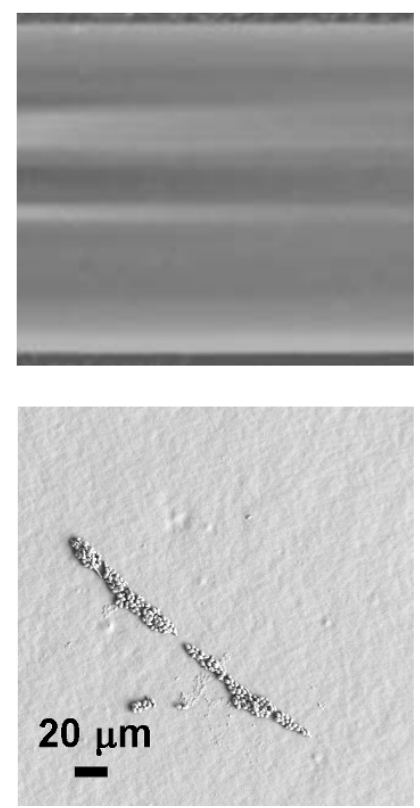

als3/als3
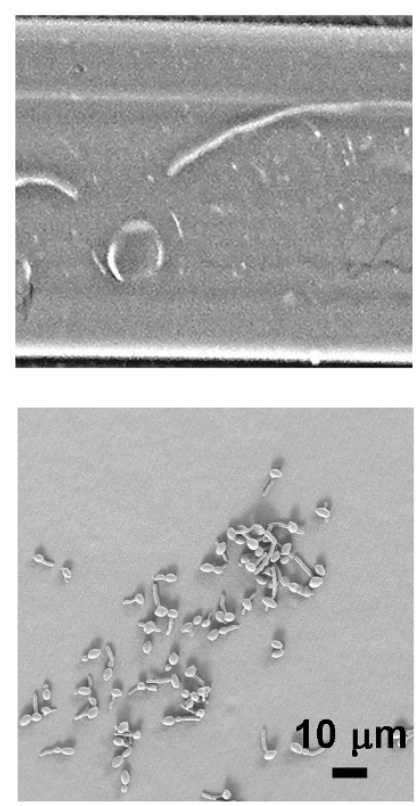

\section{Figure 5}

Influence of deletion of HWPI, BCRI and ALS3 and on establishment of early firm adhesion. Biofilms formed from the strains indicated at the top of each column were harvested at $40 \mathrm{~min}$ and the tubing was drained. The top row are pictures of the underside of the tubing. Visible biofilm remained after draining the tubing for the reference strain (DAY286) and the hwp //hwp / mutant, while no visible biofilm remained for the $b c r / / b c r l$ mutant. There was some residual biofilm left after draining the tubing colonized by the als3/als3 mutant (before the ethanol rinse steps), but the adhesion to the surface was clearly much less than the reference strain. SEM images of the tubing in the second row indicated that multilayer biofilm remained on the surface of the tubing for the reference strain and the $h p w / / h p w /$ mutant, while very few cells could be found for the bcrl/ $\mathrm{bcrl}$ and als3/als3 mutants. The most heavily colonized regions that were found are shown. (The ethanol dehydration removed all visible biofilm from the tubing for $b c r l / b c r l$ and als $3 / a l s 3$ mutant strains). 
in YPD medium indicated that differentially regulated genes in the time course were not associated with this temperature shift.

$\mathrm{K}$ means analysis produced the most meaningful patterns in the time course array data (Figure 7). Since expression levels of all 148 genes for all conditions were included in this analysis, an implicit assumption in the interpretation is that differences in gene expression levels detected between 6 and $1 \mathrm{~h}$ and 6 and $3 \mathrm{~h}$ are a temporal extension of the differential expression pattern exhibited between 3 and $1 \mathrm{~h}$. The hierarchical cluster analysis presented in Figure 6 provides some support for this assumption since it indicates that differences in expression levels between 1 to $3 \mathrm{~h}$ and 1 and $6 \mathrm{~h}$ are relatively closely related. The outlying location of the $1 \mathrm{hL} / 1 \mathrm{hF}$ condition can be interpreted as indicating that differential transcript expression between these two groups should be treated as a separate category. In support of this interpretation we were unable to correlate genes differentially regulated during the time course analysis to genes identified in the comparison of the $1 \mathrm{~h}$ firmly (1h F) and $1 \mathrm{~h}$ loosely (1h L) attached biofilms. The proximity of the $6 \mathrm{~h} / 1 \mathrm{hF}$ and $6 \mathrm{~h} / 1 \mathrm{hL}$ conditions indicates it is valid to regard these two categories as reflecting similar temporal trends in differential expression.

The seven groups of genes identified by $\mathrm{K}$ means analysis fell into distinct GO process categories summarized in

Table 2: Genes up regulated in the $\mathrm{IhF} / \mathrm{IhL}$ comparison

\begin{tabular}{|c|c|c|c|}
\hline Gene & Orf & Microarray' & RT Q-PCR ${ }^{2}$ \\
\hline \multicolumn{4}{|c|}{ Vesicular trafficking } \\
\hline SSSI & orfl9.6828.I & 1.56 & $1.63 \pm 0.01$ \\
\hline ERV29 & orfl9.4579 & 1.60 & $3.73 \pm 0.41$ \\
\hline SEC22 & orfl9.479.2 & 1.44 & $2.24 \pm 0.1$ \\
\hline EMP24 & orfl9.6293 & 1.44 & $1.24 \pm 0.1$ \\
\hline CHS7 & orf|9.2444 & 1.44 & $1.65 \pm 0.12$ \\
\hline YOPI & orf19.2168.3 & 1.55 & $1.67 \pm 0.15$ \\
\hline \multicolumn{4}{|c|}{ Glycosylation } \\
\hline PMT4 & orfl9.4109 & 1.63 & $\mathrm{ND}^{3}$ \\
\hline DPM2 & orfl9.1203.1 & 1.61 & $2.33 \pm 0.11$ \\
\hline DPM3 & orfl9.4600.1 & 1.48 & $2.12 \pm 0.2$ \\
\hline WBPI & orfl9.2298 & $\mathrm{I} .44$ & $4.75 \pm 0.11$ \\
\hline \multicolumn{4}{|c|}{ Transport } \\
\hline$A D P I$ & orfl9.459 & 1.68 & ND \\
\hline CTRI & orfl9.3646 & 1.54 & ND \\
\hline ADY2 & orfl9.1224 & 1.69 & ND \\
\hline TNAI & orfl9.2397 & 1.68 & ND \\
\hline$A L P I$ & orfl9.2337 & 1.58 & ND \\
\hline
\end{tabular}

'Average fold change

${ }^{2} \log _{2}$ ratios. Each value is the mean \pm standard deviation of two independent experiments each with three replicates.

${ }^{3}$ Not Done
Table 3, which shows the four or five most significant categories according to the $\mathrm{P}$ value. With a few exceptions, the GO process category assignments for each group were mutually exclusive which suggests that the patterns uncovered by the $\mathrm{K}$ means analysis were functionally meaningful. Categories related to carbohydrate biosynthetic processes (group 3) and interaction with the host, adhesion during symbiosis and adhesion to the host (group 7) have the most obvious possible functional relevance to the detachment phenomenon.

\section{Comparison with batch cultures indicates differential regulation of genes associated with a response to hypoxia, amino acid biosynthesis and cell surface proteins}

If inoculation conditions are made as identical as possible, batch cultures are similar to the biofilm in terms of both cell morphology (Figure 2c) and aggregation behavior (Figure 8). Since cells in the batch cultures germinate and also exhibit cohesive (cell to cell) interactions we reasoned that genes differentially regulated in the biofilm to batch comparison and the time course analysis might contain a subset of genes involved more specifically in the detachment process, rather than exclusively in morphogenesis or cell to cell cohesion. It is conventional to compare biofilm and planktonic cultures in microarray analyses, where the planktonic culture(s) serves as a sort of reference $[30,33,38]$. We compared $1 \mathrm{~h}$ and $3 \mathrm{~h}$ biofilm and batch cultures to each other since these time points bracketed the abrupt transition in which strong adhesion was lost. We used the $1 \mathrm{~h} \mathrm{~F}$ biofilm for this comparison since we were attempting to uncover genes involved in mediating adhesive interactions.

The categories of genes that were differentially regulated between the biofilm and batch cultures are summarized in Table 4. (The complete list of differentially regulated genes is given in Additional file 2). In general, genes coding for proteins involved in glycolysis, fermentation and ergosterol synthesis were upregulated while genes associated with oxidative phosphorylation and the TCA cycle were downregulated. This pattern of differential gene expression is very similar to that observed in comparisons of batch cultures grown under aerobic and relatively anaerobic conditions [39] and indicates that biofilm cells were responding to hypoxia (Figure 9). The batch comparison data were ordered with respect to the ratio of the fold changes at the $3 \mathrm{~h}$ and $1 \mathrm{~h}$ time points. There were 16 genes for which this ratio was greater than 1.5 or less than 0.66 and also appeared in the list of significantly regulated genes in the time course analysis. The 11 genes for which the ratio $(3 \mathrm{~h} / 1 \mathrm{~h})$ was greater than 1.5 exhibited a pattern of expression that was fairly tightly clustered, similar to the group 4 pattern found by K means analysis (data not shown). Among these 11 genes were four which coded for proteins involved in response to stress: ASR1, CDR4, orf19.822 and AMS1. 

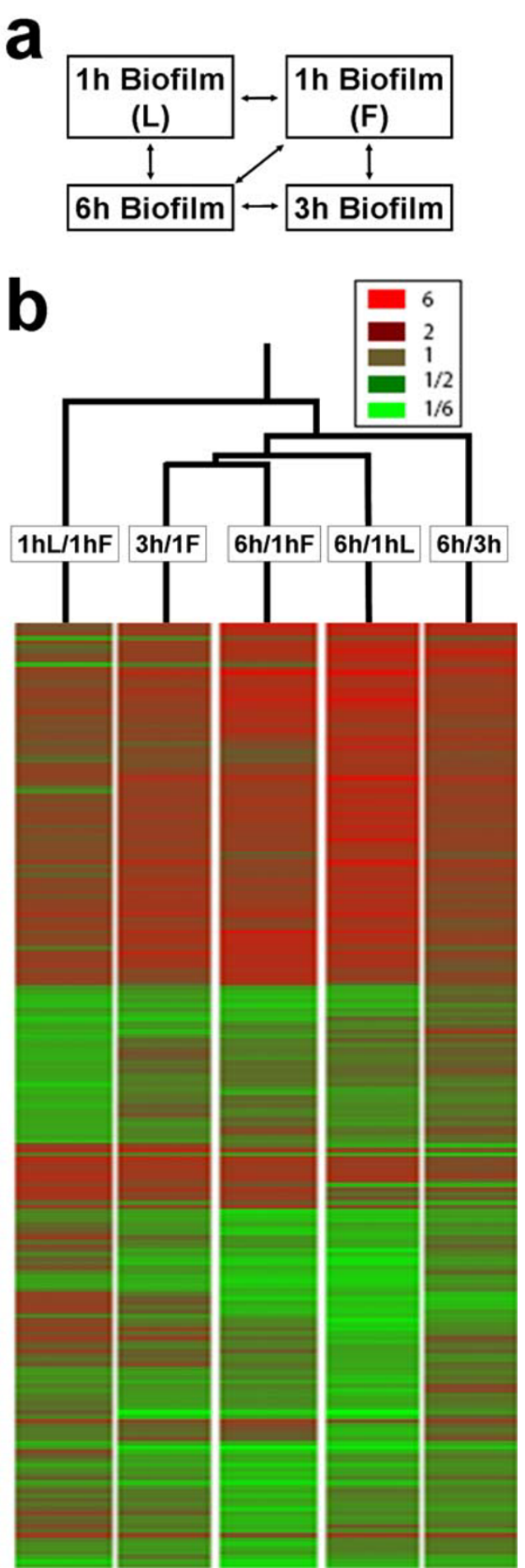

Figure 6

Time course analysis on DNA microarrays. A) Closed loop scheme. B) Heat map and two-dimensional hierarchical clustering of the different transcriptional profiles. Upregulated and downregulated genes are colored in red or green respectively.

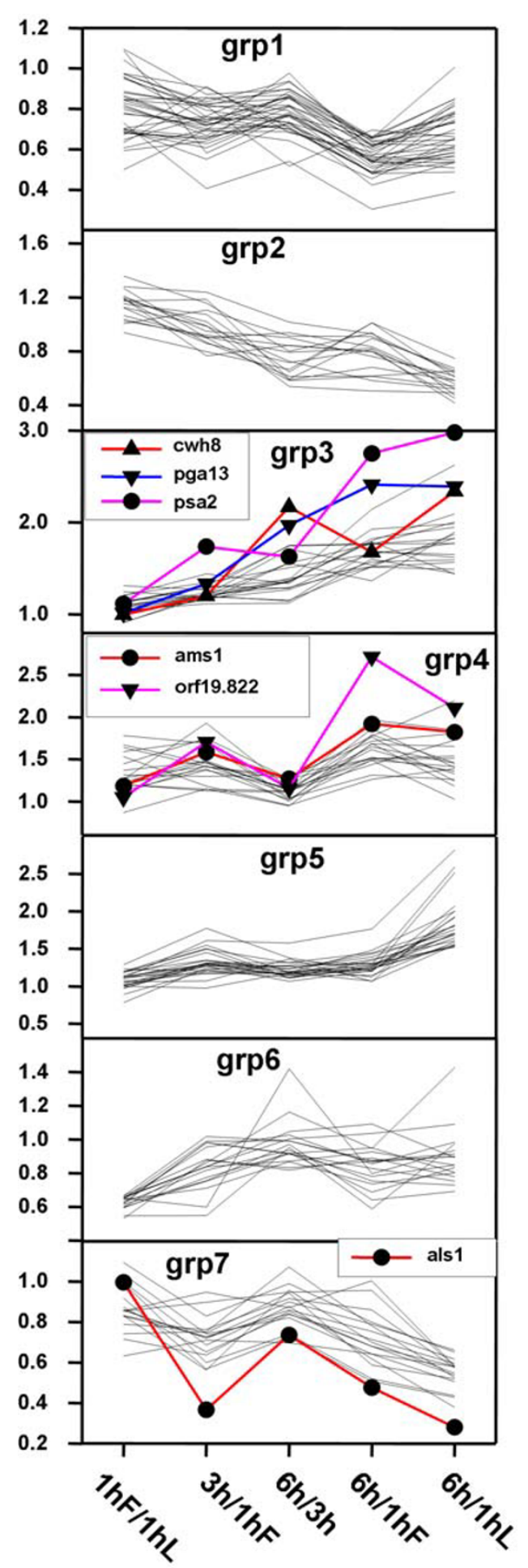

Figure 7

Categories of genes with similar expression patterns identified by $\mathbf{K}$ means analysis. The seven groups of genes fall into distinct ontological process categories summarized in Table 3. Patterns of expression of genes chosen for further analysis (groups 3, 4 and 7) are indicated. 
Table 3: Ontological categories associated with groups of genes identified by $\mathrm{K}$ means analysis of the time course array data

\begin{tabular}{|c|c|c|}
\hline Process GO term & Enrichment ${ }^{\mid}$ & $P$ value \\
\hline \multicolumn{3}{|l|}{ Group I $(17 / 37)^{2}$} \\
\hline Chromatin assembly/disassembly & 18.07 & $7.41 \mathrm{e}-5$ \\
\hline DNA packaging & 10.13 & 0.00011 \\
\hline DNA metabolic process & 4.69 & 0.00114 \\
\hline Regulation of meiosis & 39.0 & 0.00155 \\
\hline \multicolumn{3}{|l|}{ Group 2 (12/17) } \\
\hline Response to stimulus & 4.85 & 0.00063 \\
\hline Regulation of biological quality & 8.76 & 0.00087 \\
\hline Pseudohyphal growth & 20.75 & 0.00487 \\
\hline Response to stress & 4.82 & 0.00727 \\
\hline Cell growth & 15.09 & 0.00783 \\
\hline \multicolumn{3}{|l|}{ Group 3 (13/22) } \\
\hline Carbohydrate biosynthetic process & 12.75 & 0.01118 \\
\hline Glycoprotein biosynthetic process & 9.00 & 0.02203 \\
\hline Glycoprotein metabolic process & 8.50 & 0.02260 \\
\hline Response to simulus & 2.98 & 0.03761 \\
\hline Response to stress & 3.33 & 0.05641 \\
\hline Cellular carbohydrate metabolic process & 4.25 & 0.08011 \\
\hline \multicolumn{3}{|l|}{ Group $4(12 / 20)$} \\
\hline Heme metabolic process & 55.33 & 0.00066 \\
\hline Heme biosynthetic process & 55.33 & 0.00066 \\
\hline Tetrapyrrole biosynthetic process & 55.33 & 0.00087 \\
\hline Porphyrin biosynthetic process & 41.50 & 0.00087 \\
\hline Porphyrin metabolic process & 41.50 & 0.00112 \\
\hline Tetrapyrrole metabolic process & 41.50 & 0.00112 \\
\hline \multicolumn{3}{|l|}{ Group $5(10 / 24)$} \\
\hline Energy derivation/oxidation of organic compounds & $|I .1|||$ & 0.00216 \\
\hline Generation of precursor metabolites & 8.5714 & 0.00459 \\
\hline Aspartate family amino acid metabolism & 18.1818 & 0.00519 \\
\hline Sulfur metabolic process & 16.6667 & 0.00661 \\
\hline Alcohol metabolic process & 6.8966 & 0.03450 \\
\hline Metabolic process & 1.4706 & 0.05460 \\
\hline \multicolumn{3}{|l|}{ Group $6(9 / 18)$} \\
\hline Aerobic respiration & 19.5882 & 0.00041 \\
\hline Cellular respiration & 19.5882 & 0.00043 \\
\hline Energy derivation/oxidation of organics & 12.3333 & $0.001 ' 54$ \\
\hline Generation of precursor metabolites & 6.3429 & 0.00330 \\
\hline Pathogenesis & 6.3429 & 0.03922 \\
\hline Interspecies interaction & 4.9333 & 0.06136 \\
\hline \multicolumn{3}{|l|}{ Group 7 (12/18) } \\
\hline Interaction with host & 17.5263 & $5.91 \mathrm{e}-5$ \\
\hline Adhesion during symbiosis & 31.2500 & 0.00014 \\
\hline Adhesion to host & 31.2500 & 0.00014 \\
\hline Biological adhesion & 20.8333 & 0.00039 \\
\hline Pathogenesis & 9.5143 & 0.00065 \\
\hline Single species biofilm formation/biomaterial & 41.5000 & 0.00139 \\
\hline
\end{tabular}

I Ratio of the abundance in the differentially regulated gene set to the abundance in the set of genes contained in the gene ontology data base

2 Total number of classified genes/total number of genes in the group 


\section{Loss of strong adhesion is not influenced by oxygen} availability at the interface or in the medium

The porous structure of silicone elastomers results in a high gas permeability [40]. (Silicone elastomer is 25 times as permeable to oxygen as natural rubber). Thus it is likely that oxygen penetration at the tubing surface might establish a gradient of oxygen at the biofilm/surface interface.
The timing of the structural transition in which hyphae extending from the edges of the biofilm were first observed corresponds with the loss of adhesion (Figure 3) suggesting that the two phenomena might be related.

We tested the hypothesis that availability of oxygen at the biofilm/surface interface was providing a stimulus to
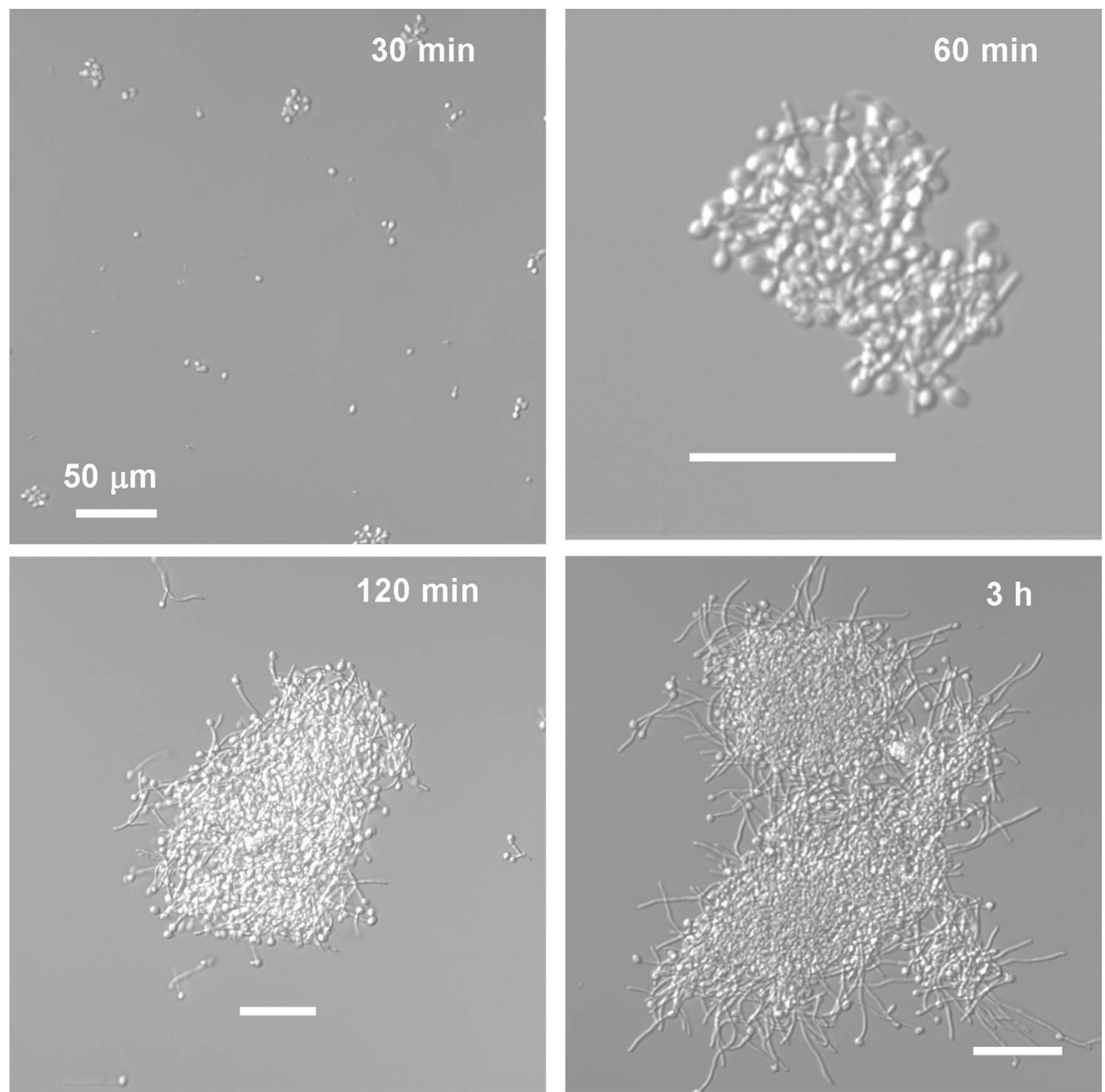

Figure 8

Cell aggregate formation in batch cultures; we did not observe alignment of germ tubes extending into the surrounding medium at the edge of any of the cell aggregates. 
induce detachment by placing a gas tight glass sleeve around the biofilm reactor and filling the sleeve with nitrogen gas. Nitrogen was induced after $40 \mathrm{~min}$ of growth to allow time for the biofilm to establish firm adhesion to the surface. The presence of the nitrogen had a measurable effect on hyphal length which was reduced by $62 \%$ compared to the standard conditions ( $29 \mu \mathrm{m}$ versus $47 \mu \mathrm{m}$, p value $1.4 \mathrm{e}-6)$. However, there was no visible difference in the detachment phenotype at $3 \mathrm{~h}$. We performed additional experiments to see if we could perturb the detachment phenotype by availability of oxygen by either filling the glass sleeve with pure oxygen or saturating the medium with pure oxygen during biofilm development. Although there were subtle perturbations in the biofilm structure (data not shown) the detachment phenotype was not appreciably altered.

\section{Mutant strain analysis suggests that transcriptional regulation of a single gene candidate is not responsible for mediating the loss of strong adhesion}

Based on the array analysis presented above we chose seven genes (AMS1, PSA2, CWH8, PGA13, orf19.822, $A Q Y 1$, and ALS1) for further analysis. (A cwh $8 /$ cwh 8 mutant could not be produced since it formed a trisomic suggesting that it is a lethal mutation). In addition to genes indicated by our array analysis, we chose two genes for further study based on their possible function in the detachment process as suggested by previous work (YWP1 and $M K C 1)[16,41]$. We also constructed a strain expressing ALS3 constitutively under the control of the ACT1 promoter based on its role in establishment of the initial firm adhesion of $1 \mathrm{~h}$ biofilms (ALS3 also exhibited down expression in the time course analysis that was just below the 1.5 fold change threshold).

The detachment phenotype of nine mutant strains was characterized using visual inspection (recorded with a digital camera), cryosections of $3 \mathrm{~h}$ biofilms, and SEM of the surface after draining the tubing. With slight variations, all the mutant strains exhibited detachment phenotypes that were quite similar. Figure 10 presents a panel of results for six of the strains tested. In the top row are mutants exhibiting detachment phenotypes that we consider essentially identical. The detachment phenotypes of the aqy1/aqy1 and $y w p 1 / y w p 1$ mutants and the orf19.822 double knockout were very similar to those shown in the top row. The

Table 4: Summary of differentially regulated genes in the biofilm-batch comparison

\begin{tabular}{|c|c|c|c|c|c|}
\hline \multirow[t]{2}{*}{ Process GO Term } & \multicolumn{2}{|c|}{ Genes on microarray dataset } & \multirow[t]{2}{*}{ Annotated Genes } & \multicolumn{2}{|c|}{$P$ value } \\
\hline & Ih-biofilm & 3h-biofilm & & Ih-biofilm & 3h-biofilm \\
\hline Up regulated genes & 130 & 127 & & & \\
\hline Lipid metabolism & 21 & 18 & & & \\
\hline Ergosterol biosynthesis & II & 9 & 28 & $1.82 \mathrm{E}-10$ & $6.67 \mathrm{E}-08$ \\
\hline Fatty acid metabolism & 3 & 4 & 74 & 0.2 & 0.1 \\
\hline Other lipid metabolism & 7 & 5 & - & - & - \\
\hline Glycolysis & 13 & 7 & 16 & $5.74 \mathrm{E}-18$ & I.75 E-07 \\
\hline Fermentation & 3 & 2 & 16 & 0.01 & 0.07 \\
\hline Amino acid biosynthesis & II & 5 & 205 & & \\
\hline Glutamate & 5 & 1 & 13 & $2.37 \mathrm{E}-05$ & 0.27 \\
\hline Leucine & 2 & 0 & 5 & $8.21 \mathrm{E}-03$ & - \\
\hline Other & 4 & 4 & - & - & - \\
\hline Transport & 12 & 4 & & & \\
\hline Glucose transport & 5 & 0 & 21 & $3 \mathrm{E}-04$ & - \\
\hline Oligopeptide transport & 3 & 0 & 11 & $3 \mathrm{E}-03$ & - \\
\hline Other & 4 & 4 & - & - & - \\
\hline Cell wall & 8 & 8 & 92 & $4.5 \mathrm{E}-03$ & $7.7 \mathrm{E}-03$ \\
\hline Protein refolding & 0 & 5 & 14 & - & 9 E-05 \\
\hline Down regulated genes & 71 & 95 & & & \\
\hline Translation (cytosolic ribosome) & II & 33 & 105 & & \\
\hline Large subunit & 8 & 18 & 50 & $9.08 \mathrm{E}-05$ & 8.I E-I5 \\
\hline Small subunit & 3 & 15 & 39 & 0.08 & $4.68 \mathrm{E}-13$ \\
\hline Tricarboxylic acid cycle & 6 & 2 & 20 & I.75 E-05 & 0.11 \\
\hline Amino acid biosynthesis & 3 & 13 & & & \\
\hline Glutamate & 0 & 4 & 13 & - & $6.2 \mathrm{E}-04$ \\
\hline Leucine & 0 & 2 & 5 & & $9 \mathrm{E}-03$ \\
\hline Other & 3 & 7 & - & - & - \\
\hline ATP synthesis & 6 & 9 & 20 & I.75 E-05 & 4.9 E-09 \\
\hline Respiratory chain & 8 & I I & 26 & 5.36 E-07 & 2.02 E-IO \\
\hline Stress response & 4 & 5 & - & - & - \\
\hline
\end{tabular}

'Number of genes in the annotated database 

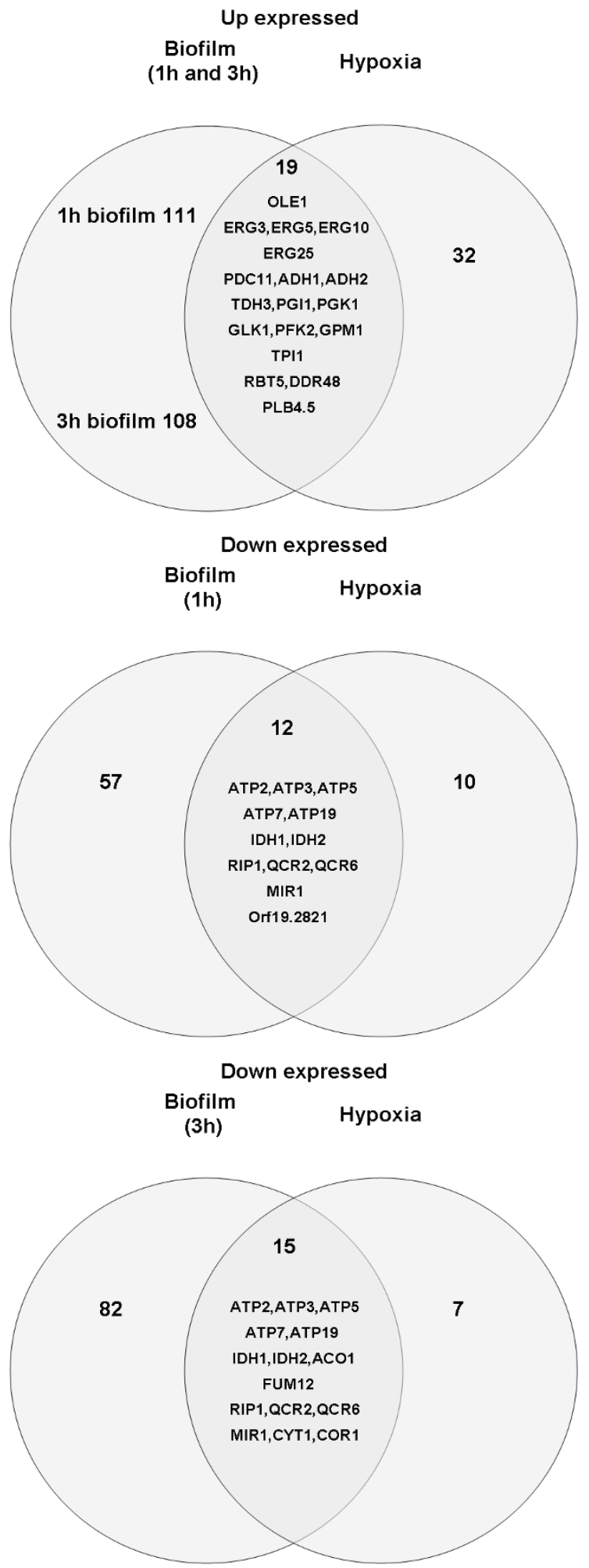

Figure 9

Common differentially regulated genes in I h and $3 \mathrm{~h}$ biofilm to batch comparison and $C$. albicans cells growing under hypoxic condition. macroscopic appearance of the psa2/psa2 mutant was similar to the reference strain but the biofilm was too fragile to withstand the application of the OCT polymer to the surface so cryosections could not be obtained. In the bottom row are detachment phenotypes that exhibited slight variations. Cryosections of the pga13/pga13 mutant did not produce hyphae that were clearly aligned at both edges of the biofilm. We tentatively attribute this to disruption of the structure during application of the OCT polymer since this biofilm had the appearance of being more fragile than that of the reference strain. In contrast, the $m k c 1 / m k c 1$ mutant produced a biofilm in which alignment of hyphae appeared to be more pronounced than in the reference strain. (The detachment phenotype of the CAI4 reference strain was the same as the BWP1 reference strain). The detachment phenotype of ACT1-ALS3 biofilm was the only one that differed appreciably from the reference strain in terms of macroscopic appearance. Compared to the reference strain this mutant exhibited fewer regions of detachment that were relatively more displaced from the surface.

\section{Discussion}

Although circumstantial evidence strongly implicates that detachment from C. albicans biofilms plays a significant role in biomaterials centered infections, there is virtually nothing known about which types of detachment events might play a role, which conditions induce detachment, or the characteristics of the biofilms responsible for the dissemination. Our biofilm model is most relevant to detachment events that might occur from vascular catheters which commonly transport a relatively rich nutrient broth (total parenteral nutrition) and are statistically among the most likely prosthetic devices to be associated with C. albicans BSI [8]. A comparison with previous results suggests that at this early stage the biofilm is at a critical stage where it can either loose its adhesive association with the silicone tubing or develop into a mature biofilm [29]. In order to have a tractable in vitro biofilm model we used an inoculum density that is higher than that expected under any conceivable hospital conditions. However, it is quite plausible that microcolonies that develop from a much smaller inoculum might respond similarly to a constant supply of rich medium and undergo a similar process of global detachment very early in their development. It is also reasonable to expect that the primary colonizers would have previously experienced a lower temperature environment such as the skin or a hospital room.

From a medical point of view, we would like to know the interplay of factors (extrinsic and intrinsic) that trigger different types of detachment events. The perception of biofilms as structured [10] differentiated [17] communities that may exhibit developmental stages that are actively 


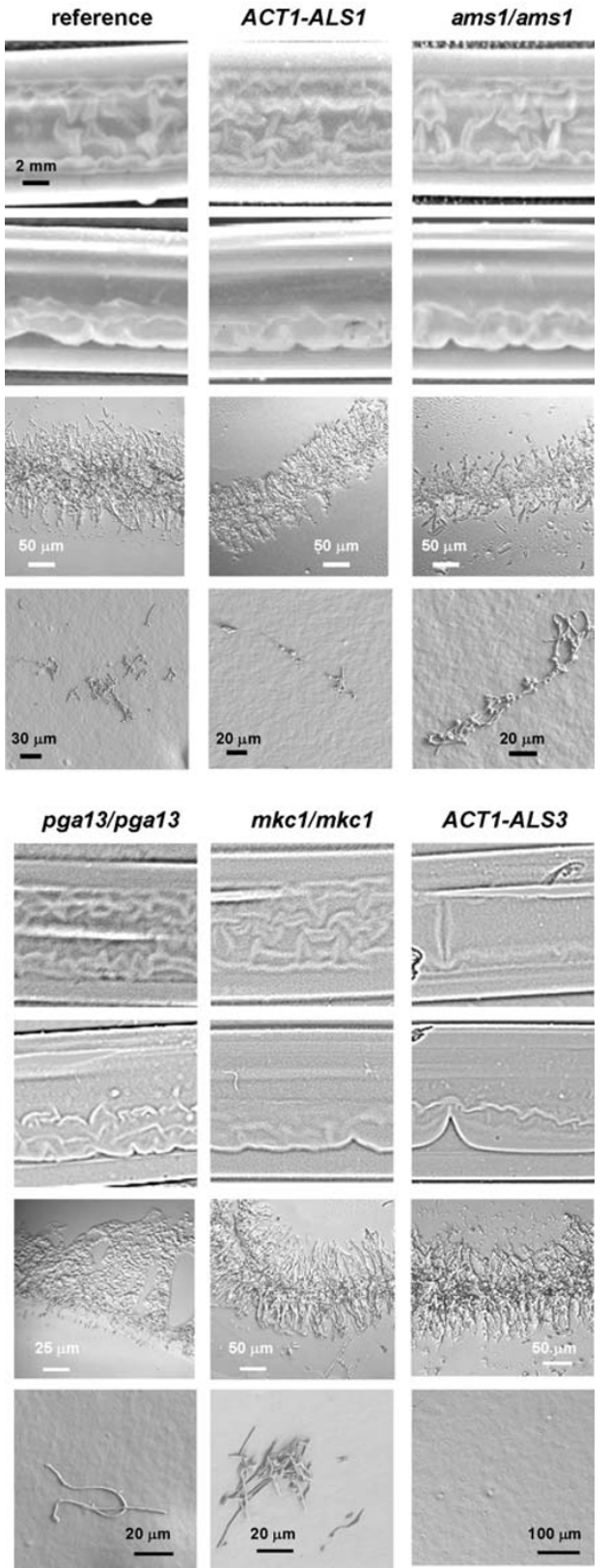

Figure 10

Detachment phenotypes of selected mutants. All data presented are for $3 \mathrm{~h}$ biofilms. The top row of panels in each set are digital camera images (top view, first row; side view, second row). The third row in each set are cryosections and the forth row are SEM images of the surface after draining the tubing. SEM images show the most densely colonized regions of the surface that could be found. The biofilm formed from the pga /3/pga / 3 mutant was relatively fragile and this may have contributed to the altered structure of the cryosections. In terms of gross structure the most pronounced differences were seen in the ACTI-ALS3 construct which exhibited fewer regions of detachment that were relatively more displaced from the surface. programmed [42] suggests that explicit intrinsic (regulatory) components might play a role. Two time course studies have provided a foundation for discovering points of active regulation of C. albicans biofilm developmental processes at the transcriptional level. Significant changes in the transcriptome accompany both the establishment of initial association with the surface [33] and precede the stage of pronounced increase in biomass [38]. This study is the first to address transcriptome changes that accompany a clearly observable biofilm detachment process. We have found that a transition in which a firm attachment to the surface is abruptly lost are coincident with changes in the transcriptome, and we have identified genes that are reasonable candidates for playing a role in this detachment. Furthermore, a subset of the genes that were differentially regulated during the transition is not associated with either hyphal extension, the most obvious morphological change at the cellular level, or cell aggregation. The microarray data indicated that changes associated with the detachment process were complex and, even after using the array data as a guide for mutant strain construction, we were unable to demonstrate that transcriptional regulation of any single gene was essential for loss of strong adhesion.

The most direct evidence that biofilm developmental processes are actively controlled by biofilm-specific transcriptional regulatory networks has come from studies of BCR1 dependent genes [11]. Bcr1p, a zinc finger domain transcription factor under the positive control of Tec $1 \mathrm{p}$, a positive regulator of morphogenesis, activates a set of genes (ALS1, ALS3 and HWP1) that code for GPI anchored cell surface proteins that are required for normal biofilm formation. Of these, ALS3 and HWP1 appear to play the most prominent role in biofilm development $[11,19,35]$, and evidence suggests that their differential expression could play a role in mediating detachment events [19]. We found that BCR1 was necessary for establishment of adhesion of the C. albicans biofilm to the silicone elastomer surface and that ALS3 was necessary for establishment of firm adhesion, while HWP1 was not required. Although there was a slight trend of decreased expression of TEC1 in the time course analysis, there was no indication that $B C R 1$ was differentially regulated during detachment and overexpression of ALS3 had only a modest effect on the detachment phenotype.

The time course analysis indicated that the detachment process coincided with differential regulation of a relative abundance of genes coding for plasma membrane proteins, cell surface proteins and cell wall proteins, with a modest enrichment in these categories (data not shown). These genes were scrutinized more closely for clues that would indicate changes in cell surface properties related to detachment. Genes involved in transport (ALP1, TNA1, 
CTR1, GNP1, HGT1, HGT15, and DUR7) were highly represented indicating a shift in metabolism. There was no clear trend indicating that these transcripts were generally either increased or decreased during the time course. There was a general decrease in transcripts for genes involved in hyphal penetration (RAC1, PLB1) which is suggestive of a response to reject surface association. It would be reasonable to expect that induction of release from the surface would involve cell wall restructuring and two genes (SCW11, XYL2) are related to this function.

Patterns of gene expression uncovered by K means analysis indicated that genes involved in similar biological processes were regulated together which provides some support for the hypothesis that the detachment process was associated with some form of coordinated transcriptional regulation. Genes involved in DNA packaging (HTB1, HTA1, HHF22, HHT2, and NHPGa) and host interaction (RAS1, SAP5, ALS1, and TEC1) were generally down regulated (groups 1 and 7 , respectively), while genes involved in carbohydrate/glycoprotein (CWH8, PSA2, and TPS3) biosynthetic processes and energy derivation/generation of precursor metabolites (TPS2, MRF1, and $A D H 5$ ) were generally up regulated (groups 3 and 5 , respectively). Among group 1 there were a number of genes coding for histones that were found to be differentially regulated by the quorum sensing agents farnesol or tyrosol (HTA1, HHT2, and NHP6a), both of which have been shown to influence biofilm development $[43,44]$.

There are a substantial number of genes whose expression levels have been shown previously to influence C. albicans biofilm formation. The BCR1 dependent genes were discussed above. The one gene (YWP1) specifically linked to C. albicans biofilm detachment [16] was notably absent from the list of differential regulated genes in the time course analysis. This was not entirely unexpected since YWP1 is expressed primarily in the yeast form. Another gene that was notably absent from the list was EAP1. The EAP1 gene has been shown to be required for strong adhesion to polystyrene, which is similar to silicone elastomer in that it is relatively hydrophobic [45]. PRP22, a gene found to be upregulated upon binding of hyphae to polystyrene [46], showed a trend of downregulation in our time course study. PRP22 is an RNA dependent ATP-ase, and thus probably involved in general metabolism so we did not consider this as a candidate for functional analysis.

A reasonable hypothesis is that detachment from a silicone elastomer surface is induced by a change in cell surface hydrophobicity (CSH). C. albicans has a variety of options for binding to host cells via specific interactions, while CSH provides a less specific means of binding to both host tissues and biomaterial surfaces [47]. Presuma- bly cell to cell cohesion within a biofilm could be maintained by a subset of the more specific interactions, while loss of CSH would weaken adhesion to the hydrophobic silicone elastomer surface. Genes implicated in determining CSH include CSH1 [48,49], MNN4 [50] and three genes that contain an eight cysteine domain that shows similarity to a class of fungal hydrophobins (CSA1, PGA10 and RBT5) [32]. CSH1 was upregulated during the time course of detachment, a result that is difficult to interpret since this would presumably enhance binding to the silicone elastomer surface. Neither MNN4 nor CSA1 (WAP1) were among the genes differentially regulated in either the time course analysis or the batch comparison. PGA10 (RBT51), coding for a (putative) mannosylated GPI anchored protein, was upregulated during the time course and RBT5, coding for a GPI-anchored cell wall protein, was upregulated by factors of, respectively, 4.7 and 16.5 in the 1 and $3 \mathrm{~h}$ biofilm/batch culture comparisons, but did not appear as a significantly regulated gene in the time course analysis. (RBT5 was also one of the genes up regulated in response to hypoxia ( 5.5 fold change) in a previous study [39]).

We attempted to exploit the comparison between $1 \mathrm{~h} F$ and $1 \mathrm{~h} \mathrm{~L}$ biofilm subpopulations to identify additional genes that were involved in mediating adhesion with the idea that the pattern of expression of these genes during the time course might suggest genes involved in the detachment process. However, genes identified in this comparison were generally not ones that appeared in the time course analysis and, in fact, the genes in this comparison exhibited a pattern of expression that was relatively removed from the time point comparisons. This is shown both by the hierarchical clustering across the different comparisons (Figure 6), and principle components analysis (data not shown). Our interpretation is that genes identified in the comparison of $1 \mathrm{~h} \mathrm{~F}$ and $1 \mathrm{~h} \mathrm{~L}$ biofilm subpopulations, many of which fall into process categories of glycosylation, vesicle trafficking and transport, are candidates for mediating cohesive (cell to cell) interactions rather than adhesive (cell to surface) interactions.

The batch cultures that we used for our biofilm/batch comparison were similar to biofilms in both morphogenesis and cell aggregation behavior, and thus we anticipated that this comparison might reveal genes associated with the biofilm-specific process of detachment. A substantial proportion of the 201 genes that were differentially regulated in the biofilm/batch comparison were probably associated with a response to a relative state of hypoxia in the biofilm (Figure 9) [39]. However, expression of 12 genes coding for cell surface proteins were not differentially regulated in the previous analysis of the $C$. albicans response to hypoxia (ALS3, CDC19, FRE10, HEM13, HSP104, HYR1, orf19.822, PGA10, PGA52, 
PGA7, PHR1, and SOD5). Of these 12 genes, the most highly upregulated gene in the $3 \mathrm{~h}$ biofilm to batch comparison was orf19.822, a gene coding for a soluble protein that is more abundant in C. albicans biofilms formed on silicone elastomer than in corresponding batch cultures [51]. A notable proportion (5 of 12) of the cell surface genes code for GPI anchored or putative GPI anchored cell wall proteins (PGA10, PGA52, PGA7 (CRW3, RBT6), PGA10 (RBT51, RBT8), and HYR1).

The patterns of gene expression across the time course conditions uncovered by K means analysis, supplemented by the biofilm/batch comparison and the inferred function suggested to us that AMS1, PSA2, CWH8, PGA13, orf19.822, AQY1, and ALS1 were candidates for playing a major role in the detachment process. Inferred functions of AMS1, PSA2, CWH8 and PGA13 indicated that these genes might play a role in restructuring the cell wall, thus possibly modifying the adhesive properties [52-54]. AMS1 and orf19.822 were among the genes identified as unique to the biofilm process according to the batch comparison. Orf19.822 codes for a protein that may contribute to biofilm formation on silicone elastomer surfaces [51]. We speculated that Aqy1p [55] might be one component in a system enabling an orientational response to oxygen gradients, since hyphal orientation is regulated by calcium ion channels [56] and aquaporins are proposed to have a role in cell tropism by acting in concert with ion channels to regulate cell volume changes [57]. AQY1 was highly up regulated in the biofilm/batch comparison. ALS1 was the major overexpressed gene in a detailed microarray studies that compared biofilms and batch cultures grown under a variety of conditions [30]. ALS1 has been described as a down stream effector of morphogenesis [58-60]. Down regulation of ALS1 was associated with detachment so a strain expressing ALS1 constitutively under the control of the ACT1 promoter was constructed. We also chose ALS3 for mutant analysis based on its apparent contribution to the establishment of firm adhesion of $1 \mathrm{~h}$ biofilms. In addition, we characterized the detachment behavior of mutants lacking expression of $M K C 1$, a mitogen activated kinase, shown previously to be involved in surface sensing [41] and YWP1, a gene shown previously to be involved in detachment of yeast forms [16]. While the mutant strains pga13/pga13, mkc1/ mkc1 and ACT1-ALS3 exhibited slight modifications in the detached biofilm phenotype, there was no strong indication that any of the gene products encoded by our candidate gene list was a primary determinant in mediating detachment.

It is possible that the detachment process we observed is not regulated at the level of transcription. Alternatively, the process could well be orchestrated by transcriptional regulation of a set of genes in a complex manner as is evi- dent from the various interacting factors that have been shown to influence $\mathrm{CSH}[50,61-64]$. An intriguing possibility is that the hyphae that extend from the edge of the detached biofilm might be phenotypically distinct from the hyphae in the interior and that this phenotypic difference is conferred at the level of transcriptional regulation. There are also numerous possible points of post-transcriptional control [65]. The first step in testing this latter hypothesis would be to compare the transcriptome with the proteome, with a focus on cell wall proteins. The fairly abrupt, clearly discernable detachment process we have described would provide an ideal system for exploring these alternative, post-transcriptional mechanisms.

The detachment processes in bacterial biofilms that show evidence of active regulation can be classified into those which are elicited by an external stimulus [23-25,66] and seeding dispersal, which occurs without applying an obvious external stimulus $[27,67,68]$. In this respect the detachment process we have described is similar to seeding dispersal since there is no obvious change in nutrient loading (or hydrodynamic shear stress). Evidence has been obtained that seeding dispersal is initiated by a change in an internal microenvironment in the biofilm [67]. The batch comparison indicated that biofilm cells were experiencing a relative state of hypoxia, and there was some evidence that this response was amplified during the time course of detachment. However, we found no evidence that oxygen availability was a factor in the detachment process. One possibility is that the detachment phenomenon originates from a change in hyphal cell surface properties that is a generic part of germination under these conditions. The early stage biofilm we examined did not exhibit the classic structure in which yeast are somehow sequestered at the base of the biofilm. It may be that these yeast are necessary for mediating the permanent adhesion to the surface, while hyphae provide an initial tenacious, but more transient anchor.

\section{Conclusion}

An early stage $C$. albicans biofilm inoculated from the yeast form onto a silicone elastomer surface and grown in rich medium under flow establishes both cohesive (cellto-cell) and relatively strong adhesive (cell-to-surface) bonds. As cells germinate and hyphae grow by linear extension the adhesive bonds are progressively weakened over an $8 \mathrm{~h}$ period. This loss of adhesion is accompanied by a structural reorganization of hyphae along the perimeter of the biofilm such that they become aligned in a direction perpendicular to the interfaces delineated by the biofilm-medium and biofilm-substratum boundaries. The most pronounced transition in both adhesion and structural reorganization occurs within the first $2 \mathrm{~h}$ of biofilm development. 
A K means analysis of microarray time course data indicated that changes in the transcriptome that accompany the loss of adhesion fell into mutually exclusive functional categories. The most relevant categories were judged to be adhesion, biofilm formation and glycoprotein biosynthesis. There was no obvious pattern to suggest that a single gene regulated the detachment process. Consistent with this finding, a functional analysis using mutant strains did not reveal any striking changes in the detachment phenotype upon deletion or overexpression of key genes.

At this point in our understanding of C. albicans biofilm detachment it is uncertain which in vitro biofilm models will be most relevant to understanding detachment processes responsible for clinical cases of biomaterial centered infections. We propose that the biofilm model in our study will be useful for charactering aspects of early detachment events that may occur in catheters carrying a relatively rich medium such as vascular catheters delivering total parenteral nutrition.

\section{Methods \\ Strains and media}

C. albicans strain SC5314 was used for microarray analysis. Other strains used in this study are listed in Table 5. Stocks were stored in $10 \%$ glycerol at $-80^{\circ} \mathrm{C}$. A $1: 1$ dilution of standard YPD $(0.5 \%$ bacto yeast extract, $1 \%$ bacto peptone, $1 \%$ glucose) was used for culturing both biofilms and planktonic (broth) cultures. This was supplemented with $1 \mathrm{mM} \mathrm{L}$-arginine, $1 \mathrm{mM}$ L-histidine and 0.5 $\mathrm{mM}$ uridine for culturing prototrophs. YPD was chosen for this study so comparisons with two other array studies could be made $[36,37]$. The carbon loading via glucose ( $55 \mathrm{mM}$ ) is similar to that used in other studies of C. albicans biofilm formation on biomaterials [72-74]

\section{Plasmid and C. albicans strain construction}

Plasmid pFA-HIS1 was used as the template to prepare the HIS1-PCR cassette, and plasmid pFA-URA3 was used to prepare the URA3-PCR cassette as previously described [75]. They both have a common DNA backbone, allowing the same oligonucleotide pair to be used for the amplification of the two PCR cassettes. The oligonucleotides used in this work are listed and described (see Additional file 3). AMS1, PSA2, PGA13 and CWH8 genes were deleted in two steps. In the first step, one allele was replaced by homologous recombination with a PCR cassette containing the HIS1 gene. The BWP17 strain was transformed with the PCR fragments, and the cells were plated onto YPD plates minus histidine. Genomic DNA of the positive colonies was analyzed by PCR for the proper integration site of the cassette. The second allele disruption was accomplished as for the first allele using the URA3-PCR cassette and the cells were plated onto YPD plates minus uridine. The colonies were again analyzed by PCR to identify the proper integration site. The complete deletion of candidate genes was confirmed by PCR using primers internal to the recombination sites amplifying ORF regions. Growth rate of mutant strains in liquid medium was similar to the wild type strain.

\section{Biofilm cultures}

Biofilms were cultured in a tubular reactor similar to that used in a previous study [29] (Figure 1). Biofilms were cultured in a $50 \mathrm{~cm}$ length of silicone elastomer tubing (Cole-Parmer, cat\#96410-15) (5 mm ID, 10 mm OD), or, for one experiment, USP class VI medical grade silicone elastomer tubing of the same dimensions (P.E.P-plastics). Medium was pumped from a $2 \mathrm{~L}$ Erlemeyer flask using a peristaltic pump which was placed upstream of a flow break followed by the biofilm reactor. After sterilization by autoclaving the entire setup was placed in an incubator at $37^{\circ} \mathrm{C}$. The inoculum was prepared as follows. $10 \mathrm{ml}$ of broth was inoculated with a single colony from a YPD agar plate. Cultures were incubated on a shaker at 280 $\mathrm{rpm}$ and $30^{\circ} \mathrm{C}$ to an $\mathrm{OD}_{600}$ of $0.4-0.5$. This was used to inoculate a fresh $10 \mathrm{ml}$ broth culture at $0.05 \mathrm{OD}_{600}$ which was grown overnight under the same conditions. From this culture $20 \mathrm{ml}$ of cells at $10^{8}$ cells $/ \mathrm{ml}$ in phosphate buffered saline (PBS) (0.1 M, pH 7.0) was prepared. The tubular reactor was clamped downstream of the air trap and, using a $20 \mathrm{ml}$ syringe, the reactor was filled by drawing the cell suspension into the tubing from the effluent end. The inoculated reactor was incubated for $1 \mathrm{~h}$ at $37^{\circ} \mathrm{C}$ before starting the medium flow at $1 \mathrm{ml} / \mathrm{min}$.

\section{Planktonic cultures}

Batch cultures were grown at $37^{\circ} \mathrm{C}$ on a shaker at 280 $\mathrm{rpm}$. Preparation of the inoculum for planktonic cultures was the same as for biofilm cultures. The medium volume of batch cultures grown for different periods of time was adjusted so that the cells would be exposed to the same volume of medium as the biofilm for each time point. Accordingly, batch cultures were all inoculated with $1 \times$ $10^{8}$ cells and cultured in final volumes of 30, 60, 90, 120 and $180 \mathrm{ml}$ for the $30,60,90,120$ and $180 \mathrm{~min}$ time points, respectively. For 90, 120 and 180 min time points the initial medium volume was $60 \mathrm{ml}$, and $30 \mathrm{ml}$ aliquots of medium were added at appropriate times.

\section{Biofilm sectioning}

Biofilms were sectioned using two methods. For embedding in Spurr's resin [76] biofilm samples were fixed in situ at $4{ }^{\circ} \mathrm{C}$ in $3 \%$ gluteraldehyde in PBS. The fixed samples were washed at room temperature for $10 \mathrm{~min}$ in 20, 50 and $100 \%$ ethanol solutions successively. Samples were incubated in a series of Spurr's: 1:2 Spurr's: propylene oxide (overnight at $4{ }^{\circ} \mathrm{C}$ ); $1: 1$ Spurr's: propylene oxide (8-10 h at room temperature), 2:1 Spurr's: propylene 
Table 5: Candida albicans strains used in the study

\begin{tabular}{|c|c|c|}
\hline Strain & Strain & Genotype \\
\hline ASI (ACTI-ALS3)' & $\frac{\text { ura3 }:: \text { imm 434arg4::"hisGhis I::hisG:: [pClp-Act I] RPS I/RPSI:: [pClp-Act I-ALS3] }}{\text { ura3 :: imm434 arg4::hisG his I::hisG }}$ & [This study] \\
\hline AS5 (ACTI-ALSI) & $\frac{\text { ura3 }:: \text { imm434arg4::hisGhis } \mid:: \text { hisG:: [pClp-Act I] RPSI/RPSI::: [pClp-Act I-ALSI] }}{\text { ura3 :: imm434 arg4::hisG his I::hisG }}$ & [This study] \\
\hline AS6 (pga/3/pga/3) & $\begin{array}{l}\text { ura3 }:: \text { imm } 434 \text { arg4 }:: \text { hisGhis } 1:: \text { hisGpga } 13 \text { ::URA3 } \\
\text { ura3 :: imm434 arg4::hisG his } 1:: \text { hisG pga I } 3 \text { ::HISI }\end{array}$ & [This study] \\
\hline AS9 (psa2/psa2) & $\begin{array}{l}\text { ura3 }:: \text { imm 434arg4:::hisGhis } 1:: \text { hisGpsa2 }:: \text { ARG4 } \\
\text { ura3 }:: \text { imm } 434 \text { arg } 4:: \text { hisG his I::hisG psa2 ::HISI }\end{array}$ & This study] \\
\hline ASIO (amsI/amsl) & ura3 :: imm434his I::hisGarg4::hisGams I ::ARG4 & [This study] \\
\hline BJ3ala (ywpl/ywpl) & $\begin{array}{l}\text { ura3 :: imm434arg4::hisGywpI ::GFP-HISI } \\
\text { ura3 :: imm434 arg4::hisG ywpI ::GFP-HISI }\end{array}$ & {$[16]$} \\
\hline BWPI7 & $\begin{array}{l}\text { ura3 }:: \text { imm } 434 \text { arg4 }:: \text { hisGhis } I:: \text { his } G \\
\text { ura3 :: imm } 434 \text { arg4::hisG his } I:: \text { hisG }\end{array}$ & [69] \\
\hline CAI4 & $\frac{\text { ura3 }:: i m m 434}{\text { ura3 :: imm434 }}$ & [70] \\
\hline CAYFI78U (als3/als3) & $\frac{\text { ura3 }:: \text { imm } 434:: \text { URA3-IRO I als3::ARG4arg4 } 4: \text { hisGhis I::hisG }}{\text { ura3 }:: \text { imm434 als3::HISI arg4::hisG his I::hisG }}$ & {$[11]$} \\
\hline CJN702 (bcrl/bcrl) & $\frac{\text { ura3 }:: \text { imm 434arg4::hisGhis } 1:: \text { hisG:::pHIS } \mid \text { bcrl }:: \text { ARG4 }}{\text { ura3 }:: \text { imm434 arg4::hisG his } 1: \text { hisG bcrl::URA3 }}$ & {$[\mathrm{II}]$} \\
\hline CJN459 (bcrl/bcrl) & $\frac{\text { ura3 }:: \text { imm 434arg4 }:: \text { hisGhis } 1:: \text { hisGber } 1:: \operatorname{Tn} 7-U A U 1}{\text { ura3 }:: \text { imm434 arg4::hisG his } 1:: \text { hisG bcrl }:: \operatorname{Tn} 7-U R A 3}$ & {$[\mathrm{II}]$} \\
\hline CM-I6I3C (mkcl/mkcl) & 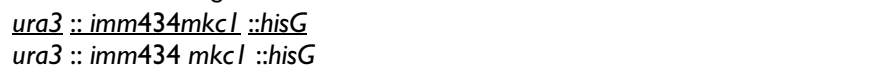 & [7I] \\
\hline DAY 286 & 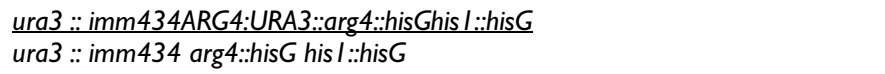 & {$[\mathrm{II}]$} \\
\hline FJS24 (hwpl/hwpl) & $\begin{array}{l}\text { ura3 :: imm 434arg4 }:: \text { hisGhis } 1:: \text { hisGhwp } 1:: \operatorname{Tn} 7-U A U I \\
\text { ura3 :: imm434 arg4::hisG his } I:: \text { hisG hwp I::Tn7-URA3 }\end{array}$ & [unpublished ${ }^{2}$ ] \\
\hline JCOI88 (aqy/aqy) & $\frac{\text { ura3 }:: \text { imm } 434 \text { aqy }:: \text { hisG-URA3-hisG }}{\text { ura3 }:: \text { imm } 434 \text { aqy ::hisG }}$ & {$[55]$} \\
\hline
\end{tabular}

I Simple genotype description for the mutants used in the study.

${ }^{2}$ Constructed by Frank J Smith

oxide (overnight at $4{ }^{\circ} \mathrm{C}$ ) and full strength Spurr's (6-8 h at room temperature). The Spurr's solution of the last incubation was replaced by a fresh one and samples were baked for $10-12 \mathrm{~h}$ in an oven at $70^{\circ} \mathrm{C}$. After cooling to room temperature, the silicone tube was removed from each sample and the hardened Spurr's column containing the biofilm was sectioned using a Reichert OM-U2 ultramicrotome. Sections were mounted on slides and imaged using a Nikon Eclipse E600 in epi-fluorescence mode.

Samples for cryosectioning were prepared by excising a section of the silicone elastomer tube used to grow the biofilm with a fresh razor blade without disturbing the biofilm. Excess medium in the tube was carefully removed using a $10 \mathrm{ml}$ syringe and needle. The tubing was cut lengthwise and the upper half was removed. The biofilm on the lower half was covered carefully with a layer of OCT (optimum cutting temperature formulation, TissueTek) and placed on dry ice until completely frozen. The tubing was carefully peeled away from the frozen biofilm by warming up the tube part briefly between fingers. The frozen biofilm sample was dipped vertically into the center of a cryosectioning cup filled with fresh OCT which was placed on dry ice until it was completely frozen. Frozen samples were sectioned at $-19^{\circ} \mathrm{C}$ using a Leica CM1850 cryostat. The $5 \mu \mathrm{m}$ thick cryosections were mounted on Superfrost/Plus microscope slides (Fisher Scientific), washed gently with distilled water to remove the excess OCT and dried at room temperature. Cryosections were imaged using a Nikon Eclipse E800 microscope interfaced to a Metaview 2.0 image acquisition system (Molecular Devices). Unstained sections were viewed in transmission using DIC optics. Sections stained with calcofluor (Fungi-Fluor ${ }^{\mathrm{TM}}$ stain, Polysciences, Inc) were viewed in epi-fluorescence mode.

\section{Antibody labeling of $(I, 3)$ glucan in biofilm cryosections} The protocol for staining biofilm cryosections for $(1,3) \beta$ glucan was a modification of a published protocol [77]. The primary monoclonal antibody $(\mathrm{mAb})$ was from Biosupplies Australia (produced in mice). The secondary anti-mouse antibody, conjugated to Alexa Fluor 488, was from Invitrogen (produced in rabbits). We used planktonic cells grown at $30^{\circ} \mathrm{C}$ and adhered to slides used for cryosectioning (Superfrost/Plus microscope slides, Fisher Scientific) as positive and negative controls. The negative 
control was omission of the primary antibody. In this case no fluorescence was detected under exposure conditions in which there was relatively bright fluorescence originating from cells exposed to the primary antibody. In addition, fluorescence was in every case associated with cells as confirmed by comparing images acquired using epi-fluorescence and transmission modes (data not shown). OCT was rinsed from the biofilm cryosections before antibody staining using Tween Tris Buffered Saline (TTBS), pH 7.6. This was followed by exposure to TTBS with $1 \%$ BSA (15 $\mathrm{min})$, exposure to the primary $\mathrm{mAb}$ at 4 ug per $\mathrm{ml}$ in TTBS $(1 \mathrm{~h})$, three washes with TTBS ( 5 min each), exposure to the secondary $\mathrm{Ab}$ at a 1:100 dilution in TTBS (30 min) and a wash with TTBS 3 times ( 5 min each).

\section{Digital camera images and movies}

Digital camera images were acquired using an Olympus SP-350 8 Megapixels digital camera at the highest resolution mode. Digital movies were recoded using a QX5 Computer Microscope (Digital Blue Inc.).

\section{Cell counts and hyphal length}

Both biofilms and planktonic cultures were exposed to 20 $\mathrm{mg} / \mathrm{ml}$ pronase in Tris buffer $(10 \mathrm{mM}$ Tris/ $\mathrm{HCl}, \mathrm{pH}$ 8.0, 2 $\mathrm{mM}$ EDTA) for $60 \mathrm{~min}$ to disperse cell aggregates according to a previously published protocol. [78] (Cell aggregates could not be dispersed sufficiently for either counting or hyphal length measurement by vortexing alone). Cells were counted in a hemacytometer. Hyphal length was measured from images acquired of dispersed cells using the Nikon/Metaview system described above.

\section{Field emission scanning electron microscopy (FESEM)}

The tubing was first drained as described in the following section. A tube section was excised and cut lengthwise into two pieces. The bottom part, where the cells settle and form the biofilm, was immersed overnight in fixing buffer (1\% paraformaldehyde, $2.5 \%$ gluteraldehyde in $0.1 \mathrm{M}$ sodium cacodylate buffer, $\mathrm{pH}$ 7.2-7.4). The fixed samples were rinsed twice for $10 \mathrm{~min}$ in $0.1 \mathrm{M}$ sodium cacodylate buffer and dehydrated twice for $5 \mathrm{~min}$ in 50\%, 70\%, 90\% and $100 \%$ ethanol solutions. Samples were dried at room temperature. Samples were coated with a thin film of iridium, $15 \mathrm{~s}$ at $20 \mathrm{~mA}$, in a Emitech sputter coater. Cells were viewed with a Supra 55VP FESEM (Zeiss) using the Inlens detector at $1 \mathrm{kV}$ and $3 \mathrm{~mm}$ working distance.

\section{RNA preparation}

Biofilm samples were collected by first clamping and then removing the colonized section of the tubing. The liquid column was drained into a $50 \mathrm{ml}$ polypropylene tube placed in an ice bath by moving the tubing to a vertical position and releasing the clamps. For $1 \mathrm{~h}$ biofilms the more firmly attached biofilm was then removed by rolling the tubing between the hands followed by flushing the tube with $25 \mathrm{ml}$ of ice-cold RNase-free water using a $50 \mathrm{ml}$ syringe to achieve the highest pressure possible. This procedure was accomplished in less than $3 \mathrm{~min}$ for each experiment. Cells from batch cultures were collected by pouring the contents of the culture flask into $50 \mathrm{ml}$ polypropylene tubes in an ice bath. Cells from biofilm or batch cultures were centrifuged at $4{ }^{\circ} \mathrm{C}$ in $10-20 \mathrm{ml}$ aliquots at $2500 \times \mathrm{g}$ for $3 \mathrm{~min}$, washed with ice-cold RNasefree $\mathrm{H}_{2} \mathrm{O}$ and immediately flash-frozen in liquid $\mathrm{N}_{2}$ and stored at $-80^{\circ} \mathrm{C}$ until use.

To release the RNA from cells, samples stored at $-80^{\circ} \mathrm{C}$ were placed on ice and RNeasy buffer RLT was added to pellets at a ratio of 10:1 [vol/vol] buffer/pellet. The pellet was allowed to thaw in the buffer while vortexing briefly at high speed. The resuspended pellet was placed back on ice and divided into $1 \mathrm{ml}$ aliquots in $2 \mathrm{ml}$ screw cap microcentrifuge tubes containing $0.6 \mathrm{ml}$ of $3 \mathrm{~mm}$ diameter acid-washed glass beads. Samples were homogenized 5 times, 1 min each, at 4200 RPM using the Mini-Beadbeater mill (Biospec Products Inc., Bartlesvile, OK, USA). Samples were placed on ice for $1 \mathrm{~min}$ after each homogenization step. After the homogenization the Qiagen RNeasy protocol was followed as recommended. Total RNA samples were eluted in RNase free $\mathrm{H}_{2} \mathrm{O}$, flash-frozen in liquid $\mathrm{N}_{2}$, lyophilized and stored at $-80^{\circ} \mathrm{C}$ until used for the different analyses.

\section{Microarray experiments: cDNA labeling, hybridizations and data analysis}

Four independent biological replicates were performed for each hybridization comparison. Labeling of the four biological replicate was performed using a dye-swap strategy that resulted in 2 experiments with $\mathrm{Cy} 3 / \mathrm{Cy} 5$ and two experiments $\mathrm{Cy} 5 / \mathrm{Cy} 3$ ratios. RNA quality and integrity were assessed using an Agilent 2100 Bioanalyzer. cDNA labeling and microarray production were performed as previously described by Nantel et al. [79]. Briefly, $20 \mu \mathrm{g}$ of total RNA was reverse transcribed using oligo $(\mathrm{dT})_{21}$ in the presence of Cy3 or Cy5-dCTP (Invitrogen) and Superscript III reverse transcriptase (Invitrogen). Thereafter, template RNA was degraded by adding 2.5 units RNase H (USB) and $1 \mu \mathrm{g}$ RNase A (Pharmacia) followed by incubation for $15 \mathrm{~min}$ at $37^{\circ} \mathrm{C}$. The labeled cDNAs were purified with QIAquick PCR Purification Kit (Qiagen). Prior to hybridization Cy3/Cy5-labeled cDNA was quantified using a NanoDrop ND-1000 UV-VIS spectrophotometer (NanoDrop) to confirm dye incorporation. Pre-hybridization and hybridization solutions consisted of DIG Easy Hyb solution (Roche Diagnostics, Mannheim, Germany) with $0.45 \%$ salmon sperm DNA and $0.45 \%$ yeast tRNA. Slides were washed once in $1.0 \%$ SSC, $0.2 \%$ SDS at $42^{\circ} \mathrm{C}$ for $10 \mathrm{~min}$, twice in $0.1 \% \mathrm{SSC}, 0.2 \%$ SDS at $42^{\circ} \mathrm{C}$ for 10 min, once in $0.1 \%$ SCC at $24^{\circ} \mathrm{C}$ for $5 \mathrm{~min}$, followed by four rinses in $0.1 \%$ SSC. Chips were air dried before being 
scanned using a ScanArray Lite microarray scanner (Perkin Elmer). QuantArray was used to quantify fluorescence intensities. Data handling, analysis and normalization were carried out using Genespring GX v.7.3 (Agilent Technologies, CA). Genes with statistically significant changes in transcript abundance in each experiment were identified using a 1.5-cutoff and Welch t-test with a False Discovery Rate (FDR) less than 5\%. Gene annotations were from http://www.candidagenome.org or http:// www.yeastgenome.org. The latter database was accessed using the DAVID search program [80].

\section{Expression analysis by real-time quantitative PCR}

cDNA was synthesized from $5 \mu \mathrm{g}$ of total RNA using the reverse-transcription system $(50 \mathrm{~mm}$ Tris- $\mathrm{HCl}, 75 \mathrm{~mm}$ $\mathrm{KCl}, 10 \mathrm{~mm}$ dithiothreitol, $3 \mathrm{~mm} \mathrm{MgCl}_{2}, 400 \mathrm{~nm}$ oligo $(\mathrm{dT})_{15}, 1 \mu \mathrm{m}$ random hexamers, $0.5 \mathrm{~mm} \mathrm{dNTP}, 200$ units Superscript II reverse transcriptase; Invitrogen). The total volume was adjusted to $20 \mu \mathrm{L}$ and the mixture was then incubated for $60 \mathrm{~min}$ at $42^{\circ} \mathrm{C}$. Aliquots of the resulting first-strand cDNA were used for real-time PCR amplification experiments. Real-time PCR was performed using the Corbett Rotor-Gene RG-3000A (Corbett Research, Sydney, Australia) with the SYBR Green PCR master mix (Qiagen) according to the manufacturer's instructions. After $10 \mathrm{~min}$ denaturation at $95^{\circ} \mathrm{C}$, the reactions were cycled 40 times at $95^{\circ} \mathrm{C}$ for $15 \mathrm{~s}, 56^{\circ} \mathrm{C}$ for $15 \mathrm{~s}$ and $72^{\circ} \mathrm{C}$ for 30 s. To verify that only the specific product was amplified, a melting point analysis was performed after the last cycle by cooling samples to $55^{\circ} \mathrm{C}$ and then increasing the temperature to $95^{\circ} \mathrm{C}$ at $0.2^{\circ} \mathrm{C}$ per second. A single product at a specific melting temperature was found for each target. All samples were tested in triplicate and the mean was determined for further calculations. Each run included a no template control to test for assay reagent contamination. To evaluate the gene expression level, the results were normalized using $\mathrm{Ct}$ values obtained from Actin (Act1, orf19.5007). The relative quantification analysis was performed using the comparative $\mathrm{Ct}$ method as described by Guillemette et al. [81].

\section{Estimation of shear stress}

Shear stress $(\tau)$ is defined as:

$$
\tau=\mu(\mathrm{dv} / \mathrm{dy})
$$

where $\mu$ is the absolute (dynamic) viscosity (approximately $10^{-2}$ dynes $\sec \mathrm{cm}^{-2}$ ). For a cylindrical geometry the slope of the velocity profile at the tube wall $(\mathrm{dv} / \mathrm{dy})$ is related to the maximum velocity $\left(\mathrm{V}_{\max }\right)$ by:

$$
\mathrm{dv} / \mathrm{dy}=2\left(\mathrm{~V}_{\max } / \mathrm{r}\right)
$$

where $\mathrm{r}$ is the radius of the tubing and:

$$
\mathrm{V}_{\max }=2 \mathrm{~V}
$$

where $\mathrm{V}$ is the mean flow velocity across the velocity profile (the volumetric flow divided by the cross sectional area of the interior of the tubing). The shear stress applied in draining the tubing was estimated from the average $\mathrm{V}$ determined from the time required for the medium plug to reach the end of the tubing (0.5s).

\section{Authors' contributions}

AS performed microarray analysis, constructed mutant strains, did PCR analysis and contributed to analysis of array data. TA cultured and characterized biofilms, and collected and purified RNA for array analysis. KM contributed to analysis of array data, particularly to K means analysis. SB performed TEM analysis. AN was primarily responsible for the design and analysis of the microarray experiments and especially the comparison with other data sets. PAS performed SEM and microscopy, contributed to array analysis and was primarily responsible for biofilm experimental design.

\section{Additional material}

\section{Additional file 1}

Biofilm Time Course Array Dataset. Complete list of differentially regulated genes

Click here for file

[http://www.biomedcentral.com/content/supplementary/14712180-9-25-S1.zip]

\section{Additional file 2}

Biofilm versus Batch Time Array Dataset. Complete list of differentially regulated genes

Click here for file

[http://www.biomedcentral.com/content/supplementary/14712180-9-25-S2.zip]

\section{Additional file 3}

Primers used in this study. Primer sequences used to construct the mutant strains

Click here for file

[http://www.biomedcentral.com/content/supplementary/14712180-9-25-S3.doc]

\section{Acknowledgements}

This work was supported by a grant from NIH (I R2 I GM070554-0IA I) to P.A.S We are grateful to Aaron Mitchell, Clarissa Nobile, Frank Smith, Bruce Granger, Jennifer Carbrey, Paola Zucchi and Carol Kumamoto for generously providing us with mutant strains. We are grateful to JeanSébastien Deneault and the members of the BRI microarray lab for technical help. We also would like to thank Hervé Hogues for bioinformatic assistance. We thank Mark Young and Trevor Douglas at MSU for their intellectual and monetary (CBIN) support. This is NRC publication number 49572.

\section{References}

I. Fridkin SK, Jarvis WR: Epidemiology of nosocomial fungal infections. Clinical Microbiology Reviews 1996, 9:499-5II.

2. Eggimann P, Garbino J, Pittet D: Epidemiology of Candida species infections in critically ill non-immunosuppressed patients. Lancet Infectious Diseases 2003, 3:685-702. 
3. Tan LH, Sun XN, Zhu XK, Zhang ZW, Li PH, Shit Q: Epidemiology of nosocomial pneumonia in infants after cardiac surgery. Chest 2004, I 25:410-417.

4. Voss A, leNoble J, Lunel FMV, Foudraine NA, Meis J: Candidemia in intensive care unit patients: Risk factors for mortality. Infection 1997, 25:8-II.

5. Macphail GLP, Taylor GD, Buchanan-Chell M, Ross C, Wilson S, Kureishi A: Epidemiology, treatment and outcome of candidemia: a five-year review at three Canadian hospitals. Mycoses 2002, 45:|4|-| 145.

6. Alonso-Valle H, Acha O, Garcia-Palomo JD, Farinas-Alvarez C, Fernanez-Mazarrasa C. Farinas MC: Candidemia in a tertiary care hospital: Epidemiology and factors influencing mortality. Eur J Clin Microbiol Infect Dis 2003, 22(4):254-257.

7. Tiraboschi IN, Bennett JE, Kauffman CA, Rex JH, Girmenia C, Sobel JD, Menichetti F: Deep Candida infections in the neutropenic and non-neutropenic host: an ISHAM symposium. Medical Mycology 2000, 38:199-204.

8. Kojic EM, Darouiche RO: Candida infections of medical devices. Clinical Microbiology Reviews 2004, 17:255-267.

9. Crump JA, Collignon PJ: Intravascular catheter-associated infections. European Journal of Clinical Microbiology \& Infectious Diseases 2000, 19:1-8.

10. Ramage G, Saville SP, Thomas DP, Lopez-Ribot JL: Candida biofilms: an update. Eukaryotic Cell 2005, 4:633-638.

II. Nobile C], Andes DR, Nett JE, Smith FJ, Yue F, Phan QT, Edwards JE, Filler SG, Mitchell AP: Critical role of Bcr I-dependent adhesins in C-albicans biofilm formation in vitro and in vivo. Plos Pathogens 2006, 2:636-649.

12. Andes D, Nett J, Oschel P, Albrecht R, Marchillo K, Pitula A: Development and characterization of an in vivo central venous catheter Candida albicans biofilm model. Infection and Immunity 2004, 72:6023-603I.

13. Mukheriee PK, Mohamed S, Chandra J, Kuhn D, Liu SQ, Antar OS, Munyon R, Mitchell AP, Andes D, Chance MR, et al.: Alcohol dehydrogenase restricts the ability of the pathogen Candida albicans to form a biofilm on catheter surfaces through an ethanol-based mechanism. Infection and Immunity 2006, 74:3804-3816.

14. Baillie GS, Douglas LJ: Effect of growth rate on resistance of Candida albicans biofilms to antifungal agents. Antimicrob Agents Chemother 1998, 42(8): 1900-1905.

15. Baillie GS, Douglas L]: Iron-limited biofilms of Candida albicans and their susceptibility to amphotericin B. Antimicrob Agents Chemother 1998, 42(8):2146-2149.

16. Granger BL, Flenniken ML, Davis DA, Mitchell AP, Cutler JE: Yeast wall protein I of Candida albicans. Microbiology-Sgm 2005, I I I:163I-1644

17. Blankenship JR, Mitchell AP: How to build a biofilm: a fungal perspective. Current Opinion in Microbiology 2006, 9:588-594.

18. Nobile C], Mitchell AP: Regulation of cell-surface genes and biofilm formation by the C-albicans transcription factor Bcrlp. Current Biology 2005, I 5: I I50- I I 55.

19. Nobile CJ, Nett JE, Andes DR, Mitchell AP: Function of Candida albicans adhesin HwpI in biofilm formation. Eukaryotic Cell 2006, 5:1604-1610.

20. Vats N, Lee SF: Active detachment of Streptococcus mutans cells adhered to epon-hydroxylapatite surfaces coated with salivary proteins in vitro. Archives of Oral Biology 2000, 45:305-3।4.

21. Allison DG, Ruiz B, Sanjose C, Jaspe A, Gilbert P: Extracellular products as mediators of the formation and detachment of Pseudomonas fluorescens biofilms. Fems Microbiology Letters 1998, 167:179-184.

22. Kaplan JB, Velliyagounder K, Ragunath C, Rohde H, Mack D, Knobloch JKM, Ramasubbu N: Genes involved in the synthesis and degradation of matrix polysaccharide in Actinobacillus actinomycetemcomitans and Actinobacillus pleuropneumoniae biofilms. Journal of Bacteriology 2004, 186:82 I3-8220.

23. Thormann KM, Duttler S, Saville RM, Hyodo M, Shukla S, Hayakawa Y, Spormann AM: Control of formation and cellular detachment from Shewanella oneidensis MR-I biofilms by cyclic diGMP. Journal of Bacteriology 2006, 188:268I-269|.

24. Morgan R, Kohn S, Hwang SH, Hassett DJ, Sauer K: BdI A, a chemotaxis regulator essential for biofilm dispersion in Pseudomonas aeruginosa. Journal of Bacteriology 2006, 188:7335-7343.
25. Gjermansen M, Ragas P, Sternberg C, Molin S, Tolker-Nielsen T: Characterization of starvation-induced dispersion in Pseudomonas putida biofilms. Environmental Microbiology 2005, 7:894-906.

26. Jackson DW, Suzuki K, Oakford L, Simecka JW, Hart ME, Romeo T: Biofilm formation and dispersal under the influence of the global regulator CsrA of Escherichia coli. Journal of Bacteriology 2002, 184:290-301.

27. Purevdorj-Gage B, Costerton WJ, Stoodley P: Phenotypic differentiation and seeding dispersal in non-mucoid and mucoid Pseudomonas aeruginosa biofilms. Microbiology-Sgm 2005, I5I:1569-1576.

28. Rice SA, Koh KS, Queck SY, Labbate M, Lam KW, Kjelleberg S: Biofilm formation and sloughing in Serratia marcescens are controlled by quorum sensing and nutrient cues. Journal of Bacteriology 2005, 187:3477-3485.

29. Khot PD, Suci PA, Miller RL, Nelson RD, Tyler BJ: A small Subpopulation of blastospores in Candida albicans biofilms exhibit resistance to amphotericin $B$ associated with differential regulation of ergosterol and beta-I,6-glucan pathway genes. Antimicrobial Agents and Chemotherapy 2006, 50:3708-37I6.

30. Garcia-Sanchez S, Aubert S, Iraqui I, Janbon G, Ghigo JM, d'Enfert C: Candida albicans biofilms: a developmental state associated with specific and stable gene expression patterns. Eukaryotic Cell 2004, 3:536-545.

31. Ramage G, VandeWalle K, Lopez-Ribot JL, Wickes BL: The filamentation pathway controlled by the EfgI regulator protein is required for normal biofilm formation and development in Candida albicans. Fems Microbiology Letters 2002, 2 I 4:95- 100.

32. Perez A, Pedros B, Murgui A, Casanova M, Lopez-Ribot JL, Martinez JP: Biofilm formation by Candida albicans mutants for genes coding fungal proteins exhibiting the eight-cysteine-containing CFEM domain. Fems Yeast Research 2006, 6: I074-1084.

33. Murillo LA, Newport G, Lan CY, Habelitz S, Dungan J, Agabian NM: Genome-wide transcription profiling of the early phase of Biofilm formation by Candida albicans. Eukaryotic Cell 2005, 4:1562-1573

34. Al-Fattani MA, Douglas LJ: Biofilm matrix of Candida albicans and Candida tropicalis: chemical composition and role in drug resistance. Journal of Medical Microbiology 2006, 55:999-1008.

35. Zhao X, Daniels KJ, Oh SH, Green CB, Yeater KM, Soll DR, Hoyer LL: Candida albicans Als3p is required for wild-type biofilm formation on silicone elastomer surfaces. Microbiology-Sgm 2006, 152:2287-2299.

36. Nantel A Dignard D, Bachewich $C$, Harcus D, Marcil A, Bouin AP, Sensen $C W$, Hogues $H$, van het Hoog M, Gordon $P$, et al.: Transcription profiling of Candida albicans cells undergoing the yeastto-hyphal transition. Molecular Biology of the Cell 2002, 1 3:3452-3465.

37. Enjalbert B, Nantel A, Whiteway M: Stress-induced gene expression in Candida albicans: Absence of a general stress response. Molecular Biology of the Cell 2003, I4:1460-I467.

38. Yeater KM, Chandra J, Cheng G, Mukherjee PK, Zhao XM, Rodriguez-Zas SL, Kwast KE, Ghannoum MA, Hoyer LL: Temporal analysis of Candida albicans gene expression during biofilm development. Microbiology-Sgm 2007, 153:2373-2385.

39. Setiadi ER, Doedt T, Cottier F, Noffz C, Ernst JF: Transcriptional response Candida albicans to hypoxia: Linkage of oxygen sensing and Efg I p-regulatory networks. Journal of Molecular Biology 2006, 36 I:399-4II.

40. Zhang $\mathrm{H}$ : The permeability characteristics of silicone rubber. In Global advances in materials and process engineering; Dallas, TX SAMPE Fall Technical Conference; 2006: I- 10 .

4I. Kumamoto CA: A contact-activated kinase signals Candida albicans invasive growth and biofilm development. Proceedings of the National Academy of Sciences of the United States of America 2005, 102:5576-558I.

42. Stoodley P, Sauer K, Davies DG, Costerton JW: Biofilms as complex differentiated communities. Annual Review of Microbiology 2002, 56:187-209.

43. Alem MAS, Oteef MDY, Flowers TH, Douglas LJ: Production of tyrosol by Candida albicans biofilms and its role in quorum sensing and biofilm development. Eukaryotic Cell 2006, 5:1770-1779. 
44. Ramage G, Saville SP, Wickes BL, Lopez-Ribot JL: Inhibition of Candida albicans biofilm formation by farnesol, a quorum-sensing molecule. Appl Environ Microbiol 2002, 68(I I):5459-5463.

45. Li F, Palecek SP: EAPI, a Candida albicans gene involved in binding human epithelial cells. Eukaryotic Cell 2003, 2: I 266-I273.

46. Marchais V, Kempf M, Licznar P, Lefrancois C, Bouchara JP, Robert R, Cottin J: DNA array analysis of Candida albicans gene expression in response to adherence to polystyrene. Fems Microbiology Letters 2005, 245:25-32.

47. Chaffin WL, Lopez-Ribot JL, Casanova M, Gozalbo D, Martinez JP: Cell wall and secreted proteins of Candida albicans: Identification, function, and expression. Microbiol Mol Biol Rev 1998 , 62(I): 130-180.

48. Singleton DR, Fidel PL, Wozniak KL, Hazen KC: Contribution of cell surface hydrophobicity protein I (Csh I p) to virulence of hydrophobic Candida albicans serotype A cells. Fems Microbiology Letters 2005, 244:373-377.

49. Singleton DR, Masuoka J, Hazen KC: Cloning and analysis of a Candida albicans gene that affects cell surface hydrophobicity. Journal of Bacteriology 200I, I 83:3582-3588.

50. Singleton DR, Masuoka J, Hazen KC: Surface hydrophobicity changes of two Candida albicans serotype B mnn4 delta mutants. Eukaryotic Cell 2005, 4:639-648.

51. Vediyappan G, Chaffin WL: Non-glucan attached proteins of Candida albicans biofilm formed on various surfaces. Mycopathologia 2006, 161:3-10.

52. Braun BR, Hoog MV, d'Enfert C, Martchenko M, Dungan J, Kuo A, Inglis DO, Uhl MA, Hogues H, Berriman M, et al.: A human-curated annotation of the Candida albicans genome. Plos Genetics 2005, I:36-57.

53. Castillo L, Martinez Al, Garcera A, Garcia-Martinez J, Ruiz-Herrera J, Valentin E, Sentandreu R: Genomic response programs of Candida albicans following protoplasting and regeneration. Fungal Genetics and Biology 2006, 43:124-134.

54. Warit S, Zhang NS, Short A, Walmsley RM, Oliver SG, Stateva LI: Glycosylation deficiency phenotypes resulting from depletion of GDP-mannose pyrophosphorylase in two yeast species. Molecular Microbiology 2000, 36: I I56-I I66

55. Tanghe A, Carbrey JM, Agre P, Thevelein JM, Van Dijck P: Aquaporin expression and freeze tolerance in Candida albicans. Applied and Environmental Microbiology 2005, 7 I:6434-6437.

56. Brand A, Shanks S, Duncan VMS, Yang M, Mackenzie K, Gow NAR: Hyphal orientation of Candida albicans is regulated by a calcium-dependent mechanism. Current Biology 2007, I 7:347-352.

57. Schwab A, Nechyporuk-Zloy V, Fabian A, Stock C: Cells move when ions and water flow. Pflugers Archiv-European Journal of Physiology 2007, 453:42 I-432.

58. Fu Y, Ibrahim AS, Sheppard DC, Chen YC, French SW, Cutler JE, Filler SG, Edwards JE: Candida albicans Als I p: an adhesin that is a downstream effector of the EFGI filamentation pathway. Molecular Microbiology 2002, 44:6I-72.

59. Zhao XM, Oh SH, Cheng G, Green CB, Nuessen JA, Yeater K, Leng RP, Brown AJP, Hoyer LL: ALS3 and ALS8 represent a single locus that encodes a Candida albicans adhesin; functional comparisons between Als3p and Als I p. Microbiology-Sgm 2004, I 50:24I5-2428.

60. Green CB, Zhao XM, Yeater KM, Hoyer LL: Construction and real-time RT-PCR validation of Candida albicans PALS-GFP reporter strains and their use in flow cytometry analysis of ALS gene expression in budding and filamenting cells. Microbiology-Sgm 2005, I 5 I: 105 I-1060.

61. Lopezribot JL, Casanova M, Martinez JP, Sentandreu R: Characterization of Cell-Wall Proteins of Yeast and Hydrophobic Mycelial Cells of Candida-Albicans. Infect Immun 1991, 59(7):2324-2332.

62. Hazen BW, Hazen KC: Dynamic Expression of Cell-Surface Hydrophobicity During Initial Yeast-Cell Growth and before Germ Tube Formation of Candida-Albicans. Infect Immun | 988, 56(9):252 |-2525.

63. Hazen KC, Hazen BW: Surface Hydrophobic and Hydrophilic Protein Alterations in Candida-Albicans. Fems Microbiology Letters 1993, 107:83-88.

64. Hazen KC, Hazen BW: Hydrophobic Surface Protein Masking by the Opportunistic Fungal Pathogen Candida-Albicans. Infect Immun 1992, 60(4):|499-I508.
65. Sachs MS: Posttranscriptional control of gene expression in filamentous fungi. Fungal Genetics and Biology 1998, 23: I 17- 125.

66. Sauer K, Cullen MC, Rickard AH, Zeef LAH, Davies DG, Gilbert P: Characterization of nutrient-induced dispersion in Pseudomonas aeruginosa PAOI biofilm. Journal of Bacteriology 2004, | 86:73|2-7326.

67. Barraud N, Hassett DJ, Hwang SH, Rice SA, Kjelleberg S, Webb JS: Involvement of nitric oxide in biofilm dispersal of Pseudomonas aeruginosa. Journal of Bacteriology 2006, 188:7344-7353.

68. Kirov SM, Webb JS, O'May CY, Reid DW, Woo JKK, Rice SA, Kjelleberg S: Biofilm differentiation and dispersal in mucoid Pseudomonas aeruginosa isolates from patients with cystic fibrosis. Microbiology-Sgm 2007, I 53:3264-3274.

69. Wilson RB, Davis D, Mitchell AP: Rapid hypothesis testing with Candida albicans through gene disruption with short homology regions. Journal of Bacteriology 1999, 181: 1868-1874.

70. Fonzi WA, Irwin MY: Isogenic Strain Construction and GeneMapping in Candida-Albicans. Genetics 1993, 134:717-728.

71. Navarrogarcia F, Sanchez M, Pla J, Nombela C: Functional-Characterization of the Mkcl Gene of Candida-Albicans, Which Encodes a Mitogen-Activated Protein-Kinase Homolog Related to Cell Integrity. Mol Cell Biol 1995, 15(4):2197-2206.

72. Baillie GS, Douglas LI: Role of dimorphism in the development of Candida albicans biofilms. Journal of Medical Microbiology 1999, 48:67I-679.

73. Hawser SP, Douglas LI: Biofilm Formation by Candida Species on the Surface of Catheter Materials in-Vitro. Infect Immun 1994, 62(3):915-921.

74. Chandra J, Mukherjee PK, Leidich SD, Faddoul FF, Hoyer LL, Douglas LJ, Ghannoum MA: Antifungal resistance of candidal biofilms formed on denture acrylic in vitro. Journal of Dental Research 2001, 80:903-908.

75. Gola S, Martin R, Walther A, Dunkler A, Wendland J: New modules for PCR-based gene targeting in Candida albicans: rapid and efficient gene targeting using 100 bp of flanking homology region. Yeast 2003, 20:1339-1347.

76. Spurr AR: A Low-Viscosity Epoxy Resin Embedding Medium for Electron Microscopy. Journal of Ultrastructure Research 1969, 26:3I-43.

77. Puschel B, Demus U, Viebahn C: Subcellular characterization of the primordial germ cell antigen $P G 2$ in adult oocytes. Histochemistry and Cell Biology 2005, I 24:275-284.

78. Rahary L, Bonaly R, Lematre J, Poulain D: Aggregation and Disaggregation of Candida-Albicans Germ-Tubes. Fems Microbiology Letters 1985, 30:383-387.

79. Nantel A: The long hard road to a completed Candida albicans genome. Fungal Genetics and Biology 2006, 43:3।I-3I5.

80. Dennis G, Sherman BT, Hosack DA, Yang J, Gao W, Lane HC, Lempicki RA: DAVID: Database for annotation, visualization, and integrated discovery. Genome Biol 2003, 4(5):P3

8I. Guillemette T, Sellam A, Simoneau P: Analysis of a nonribosomal peptide synthetase gene from Alternaria brassicae and flanking genomic sequences. Current Genetics 2004, 45:2 I4-224.

Publish with Biomed Central and every scientist can read your work free of charge

"BioMed Central will be the most significant development for disseminating the results of biomedical research in our lifetime. "

Sir Paul Nurse, Cancer Research UK

Your research papers will be:

- available free of charge to the entire biomedical community

- peer reviewed and published immediately upon acceptance

- cited in PubMed and archived on PubMed Centra

- yours - you keep the copyright 